\title{
Hydraulic and Biological Analysis of the Passability of Select Fish Species at the U.S. Geological Survey Streamgaging Weir at Blackwells Mills, New Jersey
}

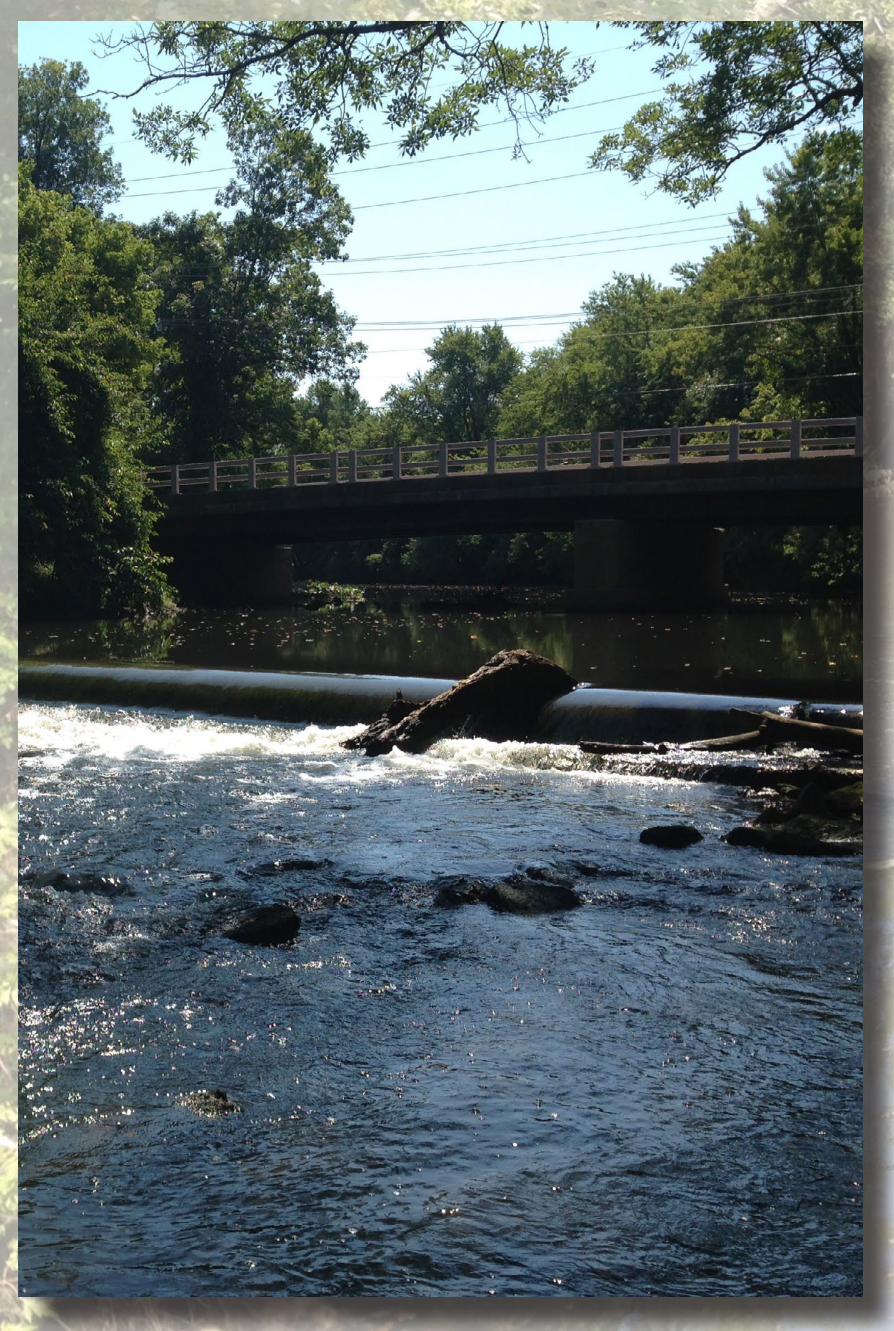

Scientific Investigations Report 2017-5103

U.S. Department of the Interior

U.S. Geological Survey 
Cover. Blackwells Mills streamgaging weir (U.S. Geological Survey 01402000), Millstone River, Hillsborough Township, Somerset County, New Jersey, August 2014. Photographs by Leanne Hillegas of the U.S. Geological Survey. 


\section{Hydraulic and Biological Analysis of the Passability of Select Fish Species at the U.S. Geological Survey Streamgaging Weir at Blackwells Mills, New Jersey}

By Alex Haro, Kevin Mulligan, Thomas P. Suro, John Noreika, and Amy McHugh

Scientific Investigations Report 2017-5103 


\title{
U.S. Department of the Interior \\ RYAN K. ZINKE, Secretary
}

\section{U.S. Geological Survey William H. Werkheiser, Acting Director}

\author{
U.S. Geological Survey, Reston, Virginia: 2017
}

For more information on the USGS - the Federal source for science about the Earth, its natural and living resources, natural hazards, and the environment-visit https://www.usgs.gov or call 1-888-ASK-USGS.

For an overview of USGS information products, including maps, imagery, and publications, visit https://store.usgs.gov.

Any use of trade, firm, or product names is for descriptive purposes only and does not imply endorsement by the U.S. Government.

Although this information product, for the most part, is in the public domain, it also may contain copyrighted materials as noted in the text. Permission to reproduce copyrighted items must be secured from the copyright owner.

Suggested citation:

Haro, Alex, Mulligan, Kevin, Suro, T.P., Noreika, John, and McHugh, Amy, 2017, Hydraulic and biological analysis of the passability of select fish species at the U.S. Geological Survey streamgaging weir at Blackwells Mills, New Jersey: U.S. Geological Survey Scientific Investigations Report 2017-5103, 15 p., https://doi.org/10.3133/sir20175103.

ISSN 2328-0328 (online) 


\section{Acknowledgments}

The authors wish to acknowledge Mark Boriek of the New Jersey Division of Fish and Wildlife and Mark Walters of the New Jersey Department of Environmental Protection, Office of Natural Resource Restoration, who provided information on target species and run timing data. The authors also thank Brett Towler from the U.S. Fish and Wildlife Service for assistance with the hydraulic analysis in this study.

Lastly, the authors wish to acknowledge Jason Shvanda and the hydrologists and hydrologic technicians of the USGS Hydrologic Data Assessment Program for providing water level data collection at the study site and analysis support. 



\section{Contents}

Acknowledgments ……...................................................................................................................

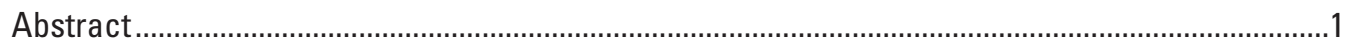

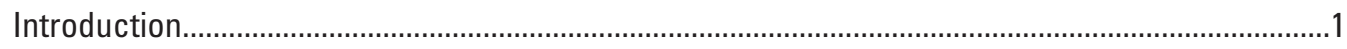

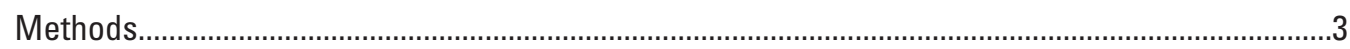

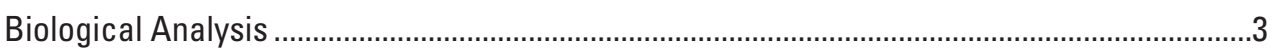

Target Species and Run Timing ............................................................................

Fish Passage Minimum Water Depth and Maximum Water Velocity Criteria ...................4

Estimated Percent Streamflow Exceedance During Migration Period .....................................4

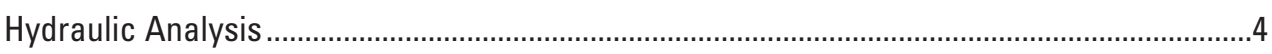

Water Surface Elevation..................................................................................................

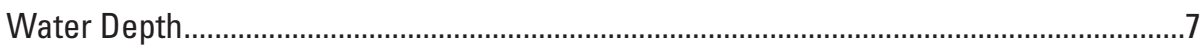

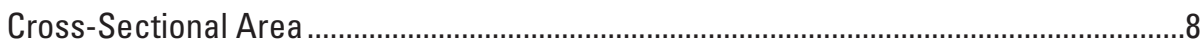

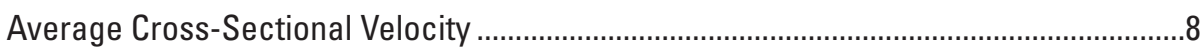

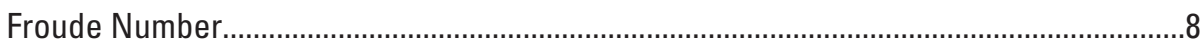

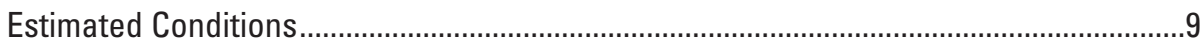

Estimated Water Depth ........................................................................................

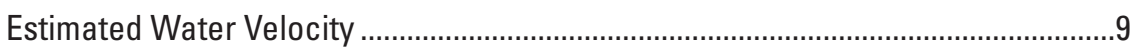

Estimated Froude Number...................................................................................11

Fish Passability During the Period of Migration ………..............................................................

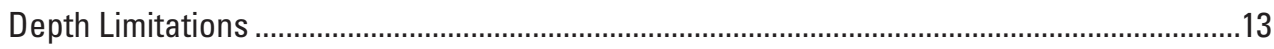

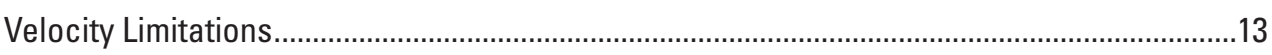

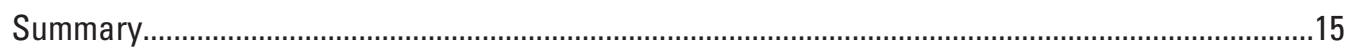

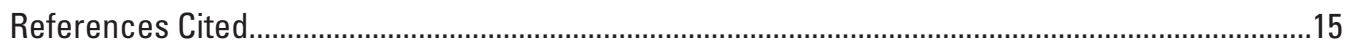

\section{Figures}

1. Map showing location of Blackwells Mills streamgage and associated weir on the Millstone River, tributary of the Raritan River, New Jersey .

2. Photographs showing the Blackwells Mills weir on the Millstone River, New Jersey for streamflows of $A$, about 710 cubic feet per second ( $\left.\mathrm{ft}^{3} / \mathrm{s}\right)$ on April 9,2014 , and $B$, about $87 \mathrm{ft}^{3} / \mathrm{s}$ on August 27, 2014.

3. Cross sections showing $A$, elevation (El.) view of the Blackwells Mills weir, New Jersey, looking downstream. $B$, Cross-sectional elevation profile of the weir center.....6

4. Graph showing streamflow rate ( 0 ) as compared to water-surface elevation for each cross-sectional location along the U.S. Geological Survey Blackwells Mills streamgage (01402000) and weir, New Jersey

5. Boxplots of estimated water depth at the center of the Blackwells Mills weir, New Jersey for $A$, point $1 ; B$, point 2 ; $C$, point 3 ; and $D$, point 4 at varying streamflow rate intervals ranging from 50 to 750 cubic feet per second ( $\left(\mathrm{ft}^{3} / \mathrm{s}\right)$ at $50 \mathrm{ft}^{3} / \mathrm{s}$ intervals.

6. Boxplots of the average cross-sectional water velocity at the Blackwells Mills weir, New Jersey, for $A$, point $1 ; B$, point 2 ; $C$, point 3 ; and $D$, point 4 with varying streamflow rate intervals ranging from 50 to 750 cubic feet per second $\left(\mathrm{ft}^{3} / \mathrm{s}\right)$ at $50 \mathrm{ft}^{3} / \mathrm{s}$ intervals. 
7. Graph showing theoretical maximum average cross-sectional water velocity along the Blackwells Mills weir, New Jersey.

8. Boxplots of the Froude number for the weir at Blackwells Mills, New Jersey, for $A$, point $1 ; B$, point $2 ; C$, point 3 ; and $D$, point 4 with each of the four points at streamflow rate intervals ranging from 50 to 750 cubic feet per second $\left(\mathrm{ft}^{3} / \mathrm{s}\right)$ at 50 $\mathrm{ft}^{3} / \mathrm{s}$ intervals

\section{Tables}

1. Passage dates for Alosa sapidissima (American shad), Alosa pseudoharengus (alewife), and Alosa aestivalis (blueback herring) at the Island Farm, New Jersey weir for selected dates 1996-2014.

2. Annual and monthly flow exceedance calculations for the U.S. Geological Survey Blackwells Mills streamgage (01402000) on the Millstone River, New Jersey, based on daily streamflow data from August 4, 1921, to January 25, 2017, and for the yearly migration season of April 14 to May 28

3. Streamflow conditions that result in insufficient depth at the center of the Blackwells Mills weir, New Jersey, for the given depth criteria from 1921 to 2017 


\section{Conversion Factors}

U.S. customary units to International System of Units

\begin{tabular}{lcl}
\hline \multicolumn{1}{c}{ Multiply } & By & \multicolumn{1}{c}{ To obtain } \\
\hline foot $(\mathrm{ft})$ & Length & \\
mile $(\mathrm{mi})$ & 0.3048 & meter $(\mathrm{m})$ \\
\hline \multicolumn{3}{c}{ kilometer $(\mathrm{km})$} \\
\hline square foot $\left(\mathrm{ft}^{2}\right)$ & 1.609 & \\
square foot $\left(\mathrm{ft}^{2}\right)$ & Area & square centimeter $\left(\mathrm{cm}^{2}\right)$ \\
\hline & 029.0 & square meter $\left(\mathrm{m}^{2}\right)$ \\
\hline cubic foot $\left(\mathrm{ft}^{3}\right)$ & Volume & \\
cubic foot $\left(\mathrm{ft}^{3}\right)$ & 28.32 & cubic decimeter $\left(\mathrm{dm}^{3}\right)$ \\
\hline & 0.02832 & cubic meter $\left(\mathrm{m}^{3}\right)$ \\
\hline foot per second $(\mathrm{ft} / \mathrm{s})$ & Water velocity & \\
\hline & 0.3048 & meter per second $(\mathrm{m} / \mathrm{s})$ \\
\hline cubic foot per second $\left(\mathrm{ft}^{3} / \mathrm{s}\right)$ & Flow rate & \\
\hline & 0.02832 & cubic meter per second $\left(\mathrm{m}^{3} / \mathrm{s}\right)$ \\
\hline feet per second squared $\left(\mathrm{ft} / \mathrm{s}^{2}\right)$ & Acceleration & \\
\hline
\end{tabular}

Temperature in degrees Celsius $\left({ }^{\circ} \mathrm{C}\right)$ may be converted to degrees Fahrenheit $\left({ }^{\circ} \mathrm{F}\right)$ as follows:

$$
{ }^{\circ} \mathrm{F}=\left(1.8 \times{ }^{\circ} \mathrm{C}\right)+32 .
$$

Temperature in degrees Fahrenheit $\left({ }^{\circ} \mathrm{F}\right)$ may be converted to degrees Celsius $\left({ }^{\circ} \mathrm{C}\right)$ as follows:

$$
{ }^{\circ} \mathrm{C}=\left({ }^{\circ} \mathrm{F}-32\right) / 1.8 \text {. }
$$

\section{Datum}

Vertical coordinate information is referenced to the National Geodetic Vertical Datum of 1929 (NGVD 29).

Elevation, as used in this report, refers to distance above the vertical datum. 


\section{Abbreviations}

$\begin{array}{ll}A_{p} & \text { cross-sectional area of the water at point }(p) \text { in feet squared } \\ \text { BD } & \text { body depth } \\ D_{p} & \text { water depth at the center of the weir at point }(p) \text { in feet } \\ F_{p} & \text { Froude number at point ( } p) \\ \text { NGVD 29 } & \text { National Geodetic Vertical Datum of 1929 } \\ p & \text { point location identifier (1 through 4) } \\ 0 & \text { streamflow in cubic feet per second } \\ T_{p} & \text { top width at point (p) in feet } \\ \text { USGS } & \text { U.S. Geological Survey } \\ V_{p} & \text { average cross-sectional water velocity at point (p) in feet per second } \\ V_{\max } & \text { theoretical maximum cross-sectional water velocity in feet per second } \\ Z_{p} & \text { water surface elevation (NGVD 29) at point ( } p \text { ) in feet }\end{array}$




\title{
Hydraulic and Biological Analysis of the Passability of Select Fish Species at the U.S. Geological Survey Streamgaging Weir at Blackwells Mills, New Jersey
}

\author{
By Alex Haro, Kevin Mulligan, Thomas P. Suro, John Noreika, and Amy McHugh
}

\begin{abstract}
Recent efforts to advance river connectivity for the Millstone River watershed in New Jersey have led to the evaluation of a low-flow gauging weir that spans the full width of the river. The methods and results of a desktop modelling exercise were used to evaluate the potential ability of three anadromous fish species (Alosa sapidissima [American shad], Alosa pseudoharengus [alewife], and Alosa aestivalis [blueback herring]) to pass upstream over the U.S. Geological Survey Blackwells Mills streamgage (01402000) and weir on the Millstone River, New Jersey, at various streamflows, and to estimate the probability that the weir will be passable during the spring migratory season.

Based on data from daily fishway counts downstream from the Blackwells Mills streamgage and weir between 1996 and 2014, the general migratory period was defined as April 14 to May 28. Recorded water levels and flow data were used to theoretically estimate water depths and velocities over the weir, as well as flow exceedances occurring during the migratory period.

Results indicate that the weir is a potential depth barrier to fish passage when streamflows are below 200 cubic feet per second using a 1-body-depth criterion for American shad (the largest fish among the target species). Streamflows in that range occur on average 35 percent of the time during the migratory period. An increase of the depth criterion to 2 body depths causes the weir to become a possible barrier to passage when flows are below 400 cubic feet per second. Streamflows in that range occur on average 73 percent of the time during the migration season. Average cross-sectional velocities at several points along the weir do not seem to be limiting to the fish migration, but maximum theoretical velocities estimated without friction loss over the face of the weir could be potentially limiting.
\end{abstract}

\section{Introduction}

The U.S. Geological Survey (USGS) Blackwells Mills streamgage (01402000) located on the Millstone River in Somerset County, New Jersey (U.S. Geological Survey, 2016) has a period of record that dates back to 1921. The Blackwells Mills streamgage is situated immediately upstream of a lowhead weir (fig. 1) that spans the full width of the river. The weir has been functioning to provide a stable low-flow control for the computation of streamflow at the streamgage since about 1937.

Together, the streamgage and weir have been essential to the management of water resources and the protection of the aquatic ecosystem in the Millstone and Raritan River systems. The streamflow data computed at the Blackwells Mills streamgage are used by the New Jersey Water Supply Authority to monitor State-mandated minimum streamflows in the downstream river reach and to manage releases from State water supply reservoirs to provide public drinking water. The streamgage needs to measure streamflow in the Millstone River upstream from the confluence of the Raritan and Millstone Rivers and downstream from the Six Mile Run tributary to preserve the historic dataset and statistics. The weir provides reliable and accurate streamflow data during low-flow conditions when the natural stream channel is insensitive to changes and subject to scour and fill shifting. Scour and fill shifting reduces the accuracy of computed low flows; therefore, the suggested alternatives of removing the weir, backwatering the weir, or notching the weir would each likely result in an insensitive or unstable streamflow control that would be subject to increased shifting and error in the computed streamflow. The need to calculate and provide accurate streamflow data for public water supply at low-flow conditions and the lack of suitable alternative methods of providing a stable and reliable low-flow control supports retention of the weir. 


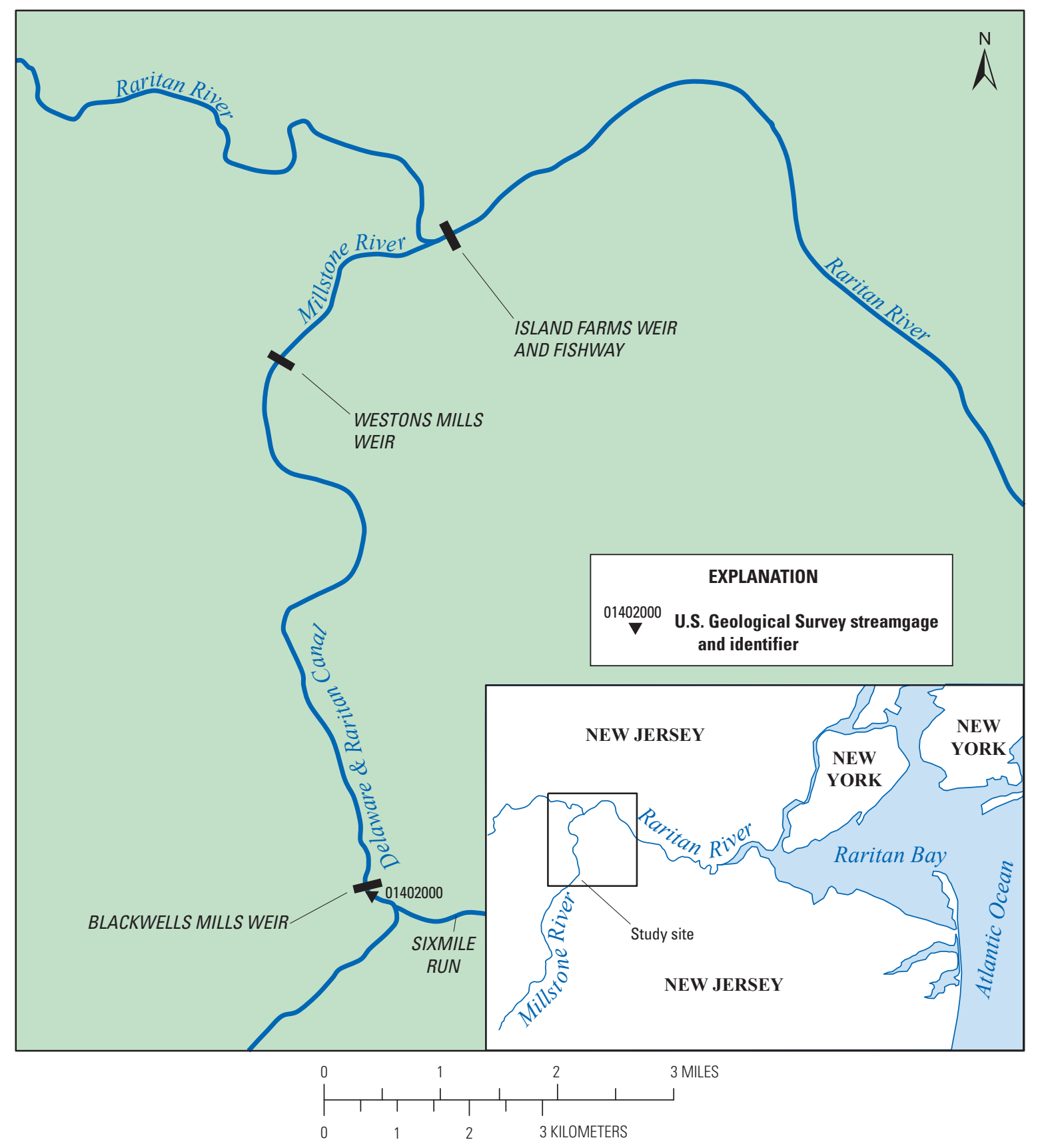

Figure 1. Location of Blackwells Mills streamgage and associated weir on the Millstone River, tributary of the Raritan River, New Jersey.

However, recent efforts to reestablish river connectivity for the Millstone River watershed (New Jersey Department of Environmental Protection, 2013; Princeton Hydro LLC, 2011) have considered removal of the weir to provide unrestrained passage of migratory fishes and other aquatic species. Passage of fish over the low-head weir is dependent on several conditions, including swimming performance of the fish species in question and the hydraulic conditions (for example, water velocity and depth) at the weir.
The purpose of this report is to document methods and results of a desktop modelling exercise to evaluate the potential ability of three anadromous fish species (Alosa sapidissima [American shad], Alosa pseudoharengus [alewife], and Alosa aestivalis [blueback herring]) to pass upstream over the USGS Blackwells Mills weir on the Millstone River, New Jersey, at various streamflows (fig. 2). The USGS performed this exercise to integrate physical hydraulics of the weir with fish swimming speed and water-depth requirements to estimate the 
$\boldsymbol{A}$

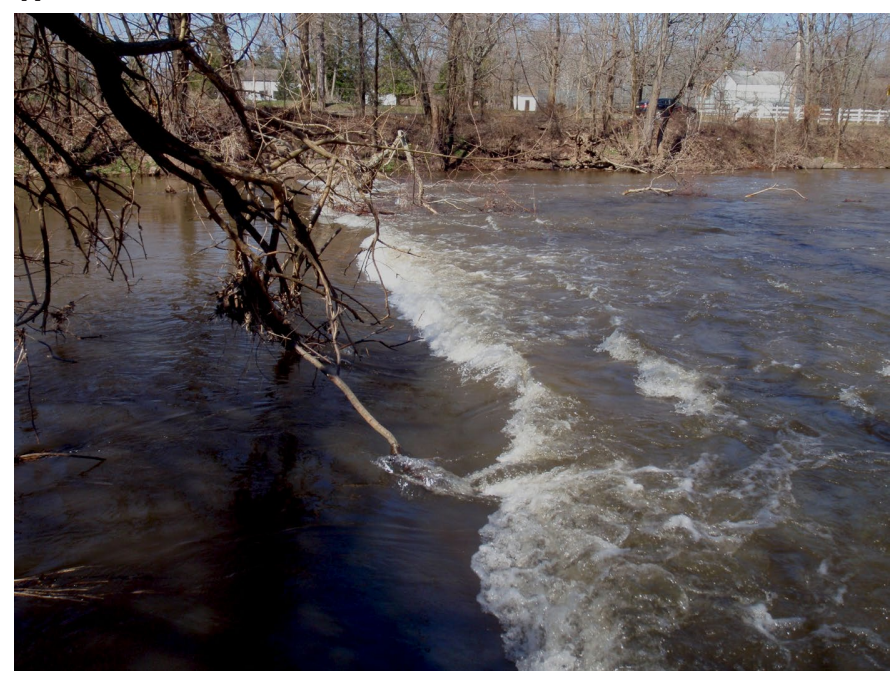

B

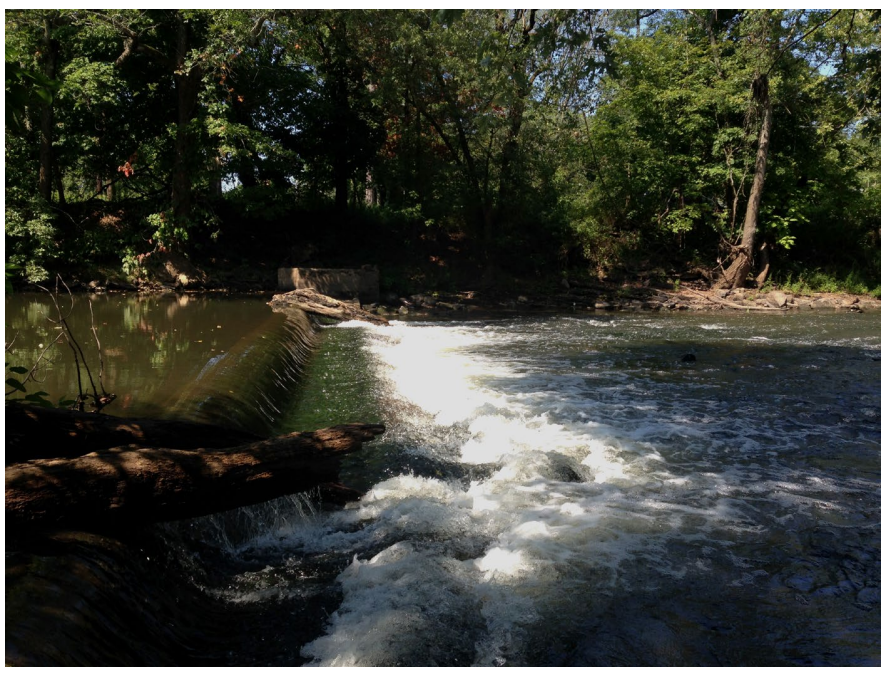

Figure 2. The Blackwells Mills weir on the Millstone River, New Jersey for streamflows of $A$, about 710 cubic feet per second ( $\mathrm{ft}^{3} / \mathrm{s}$ ) on April 9, 2014, and $B$, about $87 \mathrm{ft}^{3} / \mathrm{s}$ on August 27, 2014. The high April flow example is likely passable by the target species, where the low August flow is not likely to be passable because of high velocities and low-flow depths at the weir face. Photographs by Alex Haro (A), and Leanna Hillegas (B), U.S. Geological Survey.

critical lower and upper limits to the streamflow range under which the weir may be passable and to provide an estimate of the probability that the weir will be passable during the spring migratory season. This analysis can be used as a rationale for further research to monitor and characterize the species and numbers of fish able to ascend the river to the weir and what proportion of fish can pass the weir under current (2017) conditions. This report does not include a site survey and physical measurements of the streamflow in the area of the weir at various streamflow rates that are needed to calibrate theoretical equations and more accurately estimate the conditions.

\section{Methods}

The streamflow record from the Blackwells Mills streamgage was used to compute streamflow exceedance percentiles for the annual fish migratory period from April 14 to May 28. The target species of fish, their associated migratory timings, depth requirements, and sprint speeds also were identified. The computed streamflow exceedance percentiles at the Blackwells Mills streamgage were used to determine the range of streamflow occurring during the migratory period. The hydraulic properties of the weir were then computed using gage-height and streamflow data at the Blackwells Mills streamgage, data from a temporary water level logger installed downstream from the weir, and the original drawings of the weir. These properties include estimates of water depths, velocities, and Froude numbers along the weir structure. The results were examined to determine the limiting extent of the weir to fish passage.

\section{Biological Analysis}

\section{Target Species and Run Timing}

Target species to be considered for passage in this exercise were identified as adult American shad, alewife, and blueback herring (M. Boriek, principal fisheries biologist, U.S. Fish and Wildlife Service, written commun., 2014). Other migratory and nonmigratory fish species present at this site (for example, Anguilla rostrata [American eel] and Catostomus commersonii [white sucker]) may also require passage but are not presently considered in this exercise.

Run timing data were obtained from daily fishway counts of the three target species at the Island Farm weir fishway on the main stem Raritan River, 6.2 river miles downstream from Blackwells Mills weir (fig. 1). Counts were compiled from 1996-99, 2001-3, 2005, and 2014. Alewife and blueback herring were collectively counted at the fishway as "river herring." Count data were lacking for alewife and blueback herring for 1996 and 2005. Dates of 5- and 95-percent cumulative passage were determined for each year because these values more accurately represent run timing than dates of first and last fish passing, which can be affected by fishway operations (for example, the fishway opening date; table 1).

Median dates of 5- and 95-percent passage between 1996 and 2005 were calculated as April 15 and May 28 for American shad and April 14 and May 24 for alewife and blueback herring. The distance between the Island Farm weir fishway and Blackwells Mills weir (6.2 river miles) is not considered large enough to markedly offset (delay) run timing at Blackwells Mills because the target species should theoretically (assuming no intermediate barriers; the Westons Mills weir 
Table 1. Passage dates for Alosa sapidissima (American shad), Alosa pseudoharengus (alewife), and Alosa aestivalis (blueback herring) at the Island Farm, New Jersey weir for selected dates 1996-2014.

[Location of weir shown in figure 1. \%, percent; --, no data; Data provided by the New Jersey Department of Environmental Protection (2013)]

\begin{tabular}{|c|c|c|c|c|c|c|c|c|c|c|}
\hline \multirow[b]{2}{*}{ Year } & \multicolumn{5}{|c|}{ American shad } & \multicolumn{5}{|c|}{ Alewife and Blueback herring } \\
\hline & $\begin{array}{c}\text { Total } \\
\text { number } \\
\text { passed }\end{array}$ & $\begin{array}{c}\text { First } \\
\text { passage } \\
\text { date }\end{array}$ & $\begin{array}{c}5 \% \\
\text { passage } \\
\text { date }\end{array}$ & $\begin{array}{c}95 \% \\
\text { passage } \\
\text { date }\end{array}$ & $\begin{array}{c}\text { Last } \\
\text { passage } \\
\text { date }\end{array}$ & $\begin{array}{c}\text { Total } \\
\text { number } \\
\text { passed }\end{array}$ & $\begin{array}{c}\text { First } \\
\text { passage } \\
\text { date }\end{array}$ & $\begin{array}{c}5 \% \\
\text { passage } \\
\text { date }\end{array}$ & $\begin{array}{c}95 \% \\
\text { passage } \\
\text { date }\end{array}$ & $\begin{array}{c}\text { Last } \\
\text { passage } \\
\text { date }\end{array}$ \\
\hline 1996 & 46 & April 25 & April 29 & June 09 & June 11 & -- & -- & -- & -- & -- \\
\hline 1997 & 76 & May 02 & May 06 & June 16 & June 21 & 117 & May 03 & May 06 & June 11 & June 29 \\
\hline 1998 & 149 & April 07 & April 15 & May 31 & June 21 & 9 & April 30 & April 30 & June 11 & June 11 \\
\hline 1999 & 584 & April 08 & April 11 & May 28 & June 04 & 133 & April 22 & April 28 & May 24 & May 26 \\
\hline 2001 & 717 & April 04 & April 13 & May 23 & June 21 & 61 & April 07 & April 13 & June 16 & June 26 \\
\hline 2002 & 1,114 & April 01 & April 13 & June 01 & June 18 & 17 & April 14 & April 14 & May 10 & May 10 \\
\hline 2003 & 362 & March 26 & March 29 & May 20 & May 30 & 12 & March 29 & March 29 & May 03 & May 03 \\
\hline 2005 & 13 & April 19 & April 19 & May 14 & May 14 & -- & -- & -- & -- & -- \\
\hline 2014 & 270 & April 10 & April 15 & May 18 & June 01 & 120 & April 06 & April 10 & May 18 & May 27 \\
\hline Median date & & April 08 & April 15 & May 28 & June 11 & -- & April 14 & April 14 & May 24 & May 27 \\
\hline
\end{tabular}

may be considered for removal) be able to transit this distance in 1 day or less. Given the similarities of the run timing windows for all species, a single collective run timing window for the target species was established as April 14 to May 28 to simplify the analysis.

\section{Fish Passage Minimum Water Depth and Maximum Water Velocity Criteria}

Depth and water-velocity standards for passage of alewife, blueback herring, and American shad over lowhead dams and other weir-like structures are not universally accepted. The U.S. Fish and Wildlife Service's fishway design criteria recommend a minimum water depth of 2 body depths (BDs) to safely allow fish to pass weirs with body and median fins completely submerged (U.S. Fish and Wildlife Service, 2016). Water depths along the weir were compared to the $2-\mathrm{BD}$ criteria in addition to $1-\mathrm{BD}$, assuming that $1-\mathrm{BD}$ is the absolute minimum depth at which any fish within each species' population would be able to pass over the weir. Furthermore, BD was calculated using the nominally largest-sized adult individuals for northeastern populations, as reported by Haro and others (2004):

- $\mathrm{BD}=0.29$ foot $(\mathrm{ft})$ for alewife

- $\mathrm{BD}=0.25 \mathrm{ft}$ for blueback herring

- $\mathrm{BD}=0.60 \mathrm{ft}$ for American shad

Haro and others (2004) provide data on absolute sprint swimming speeds suitable for evaluating the ability of these species to swim over the short distance required to ascend the Blackwells Mills weir. Maximum water-velocity criteria were established as 8.0 feet per second ( $\mathrm{ft} / \mathrm{s})$ for alewife and blueback herring and $10.0 \mathrm{ft} / \mathrm{s}$ for American shad; these speeds correspond to sprint swimming speeds at which greater than 80 percent of individuals can transit the concrete weir structure, which has a breadth (longitudinal thickness) of $6.5 \mathrm{ft}$ (Haro and Castro-Santos, 2004; Haro and others, 2004).

\section{Estimated Percent Streamflow Exceedance During Migration Period}

The amount of water passing the weir dictates the depths and velocities the fish will encounter during the migration period. The migration period occurs in late spring when streamflows are generally higher than those observed in late summer, which is when the lowest flows of the year are typically observed. Streamflow exceedance calculations (Dingman, 1994) for the Blackwells Mills streamgage based on daily streamflow data from August 4, 1921, to January 25, 2017, and during the migration season period (April 14 to May 28) are shown in table 2.

\section{Hydraulic Analysis}

The hydraulic properties of the weir for a range of streamflow rates were determined to assess the passability of the weir. The Blackwells Mills weir is a nonstandard weir shape, with similarities to ogee and broad-crested weirs (fig. 3). We did not identify any literature that provides a weir discharge coefficient calibrated to this nonstandard shape. The lack of a reliable discharge coefficient prevents a conventional, direct calculation of velocity.

Elevation and cross-sectional dimensions of the Blackwells Mills weir used in the hydraulic model were derived 


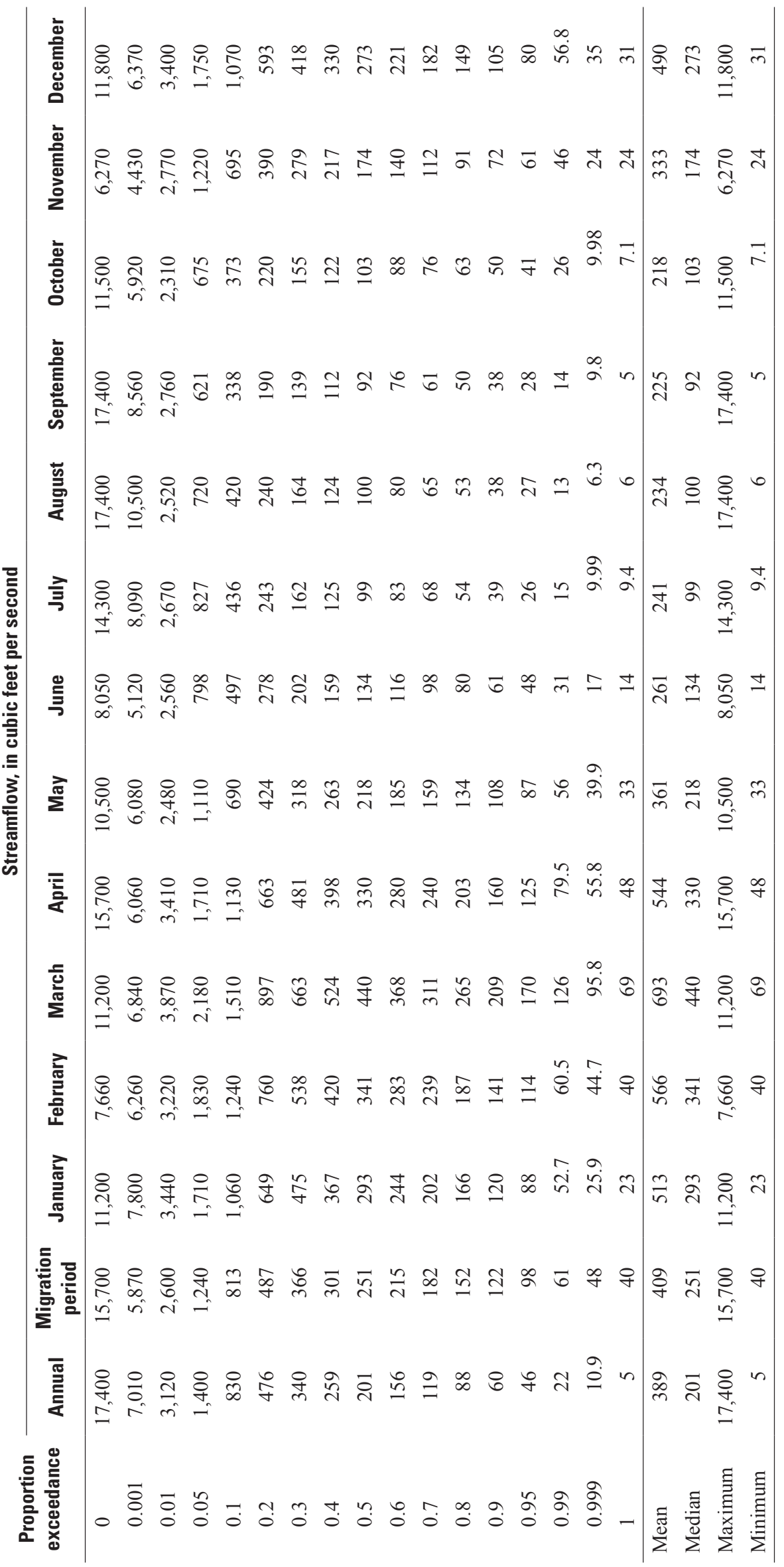



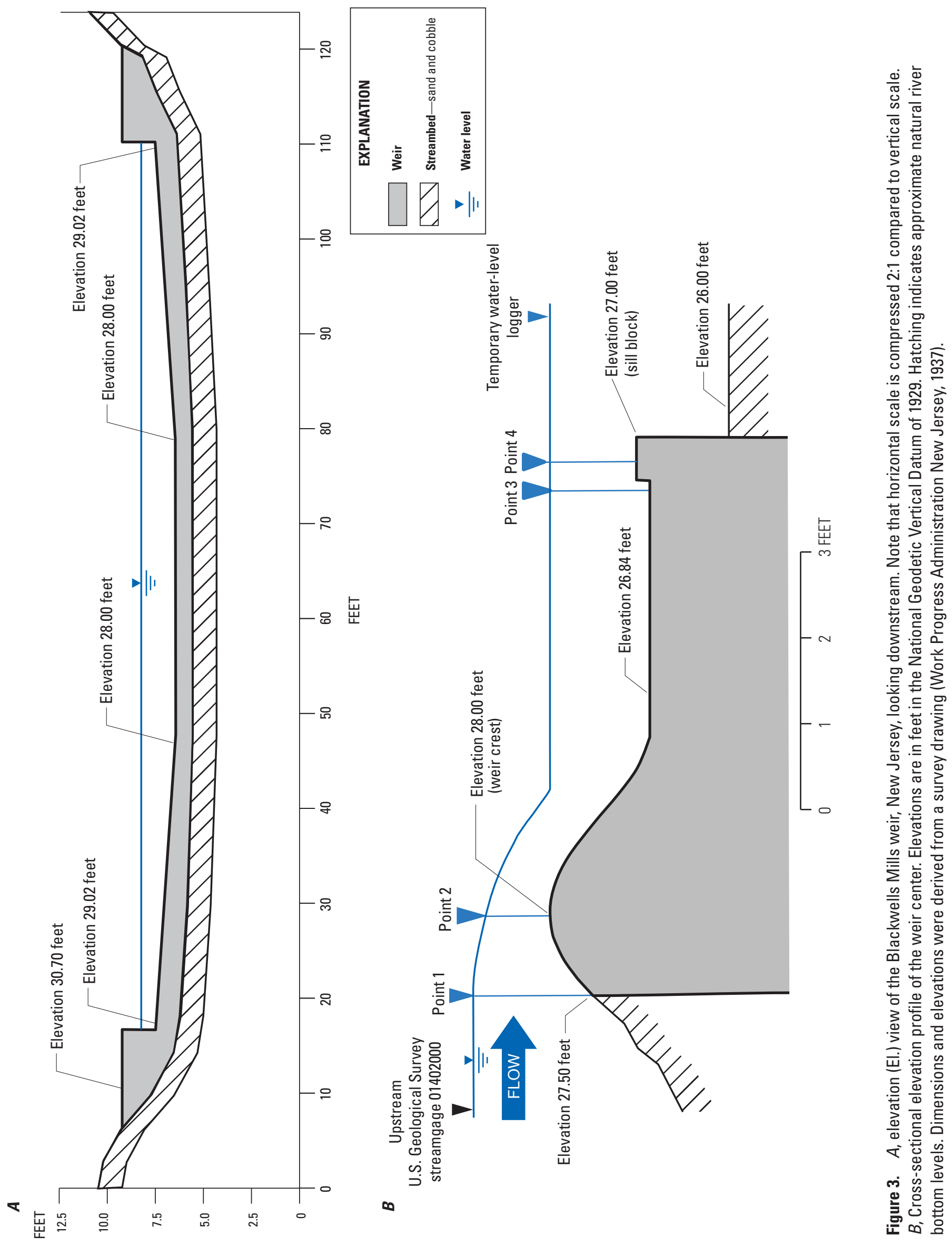
from survey drawings (Work Progress Administration New Jersey, 1937). Four important water surface elevations above the longitudinal length of the weir (points 1, 2,3, and 4), and the approximate locations where the water levels were measured by the Blackwells Mills streamgage (upstream) and the temporary water level logger (downstream), are shown in figure $3 B$. Point 1 is above the most upstream section of the concrete weir, point 2 is above the weir crest, point 3 is downstream from the weir crest and immediately upstream from the (raised) sill block lip at the downstream edge of the structure, and point 4 is above the raised sill block lip.

To evaluate the effect of the Blackwells Mills weir on fish passage, streamgage data were used to estimate the water depth, the average cross-sectional velocity, and the Froude numbers for the four locations along the longitudinal length of the weir. Point 1 represents the water surface elevations measured by the Blackwells Mills streamgage. The datum of the streamgage is $26.97 \mathrm{ft}$ above the National Geodetic Vertical Datum of 1929 (NGVD 29). Streamflow is computed using a standard stage-discharge relation at this streamgage. The streamgage height of zero flow for the stage-discharge relation is added to the datum of the streamgage to compute an elevation of zero flow of the weir crest of $28.0 \mathrm{ft}$, which matches the elevations on the weir plans. As previously stated, an additional water-level logger was installed downstream from the weir (immediately downstream from point 4). This additional water-level logger provided instantaneous tail-waterlevel data recorded to the same datum as the Blackwells Mills streamgage at 15-minute intervals from August 1 to December 23, 2014, for direct comparison with the upstream level data.

For the period with the additional water-level logger, streamflows ranged from 49 to 2,840 cubic feet per second $\left(\mathrm{ft}^{3} / \mathrm{s}\right)$ during the data collection period; headpond (point 1 ; upstream of the weir) levels ranged from 28.48 to $34.77 \mathrm{ft}$ NGVD 29 and tail-water (downstream of the sill on the weir and assumed equal to point 4) levels ranged from 27.11 to $34.66 \mathrm{ft}$ NGVD 29. The tail-water elevations were above the weir crest (28 ft NGVD 29 in the center of the weir) at streamflows greater than about $320 \mathrm{ft}^{3} / \mathrm{s}$. Several assumptions and (or) approximations were made to estimate water depths at points 2 and 3 and velocities at various streamflow rates as discussed in the following sections.

\section{Water Surface Elevation}

An application of the Bernoulli Equation (Crowe and others, 2005), along with several key assumptions, describes the water surface over the weir. Neglecting friction losses along the weir and any substantial increase in velocity between the Blackwells Mills streamgage and point 1, the water surface elevation (NGVD 29) at point $1\left(Z_{1}\right)$ is about equal to that of the water stage recorded at the Blackwells Mills streamgage. Furthermore, provided the weir crest remains unsubmerged (that is, the tail-water elevation remains at or below the elevation of the weir crest), the critical depth will be about twothirds of the total head above the crest (point 1) and will occur approximately over the crest (Crowe and others, 2005). Based on these assumptions, the relation between water surface elevation over the crest at point $2\left(Z_{2}\right)$ and the upstream elevation $\left(Z_{1}\right)$ is calculated using the following equation if the weir is unsubmerged (tail-water elevation less than $28 \mathrm{ft}$ ):

$$
Z_{2}=\frac{2}{3}\left(Z_{1}-28+\frac{V_{1}^{2}}{2 g}\right)+28
$$

where

$V_{1} \quad$ is the average upstream velocity at point 1 (see equation 4) provided the downstream water surface remains below the weir crest elevation of $28 \mathrm{ft}$ NGVD 29; and

$g \quad$ is the gravitational acceleration, equal to 32.174 feet per second squared $\left(\mathrm{ft} / \mathrm{s}^{2}\right)$.

In examining the recorded water levels, the tail-water was approximately equal to the weir crest at streamflows between $310 \mathrm{ft}^{3} / \mathrm{s}$ and $365 \mathrm{ft}^{3} / \mathrm{s}$ (mean of $320 \mathrm{ft}^{3} / \mathrm{s}$ ). At streamflows greater than $388 \mathrm{ft}^{3} / \mathrm{s}$, the tail-water elevation clearly exceeds $28 \mathrm{ft} \mathrm{NGVD} 29$ and the weir is submerged. When the crest is submerged (that is, the tail-water elevation is greater than the elevation of the weir crest), equation 1 may not be valid; under such conditions, a complex hydraulic model and (or) field evaluations may be required to determine the relation between $Z_{1}$ and $Z_{2}$. To ensure the applicability of equation 1 , only flows corresponding to downstream water level measurements less than or equal to $28 \mathrm{ft}$ NGVD 29 were analyzed for point 2 .

The water surface elevation at point $3\left(Z_{3}\right)$, immediately upstream from the sill block, was assumed to be equal to the water surface elevation at the downstream water level logger. The water surface elevation at point $4\left(Z_{4}\right)$, above the sill block, was also assumed to be equal to the water surface elevation at the downstream water level logger. Water levels recorded downstream from the weir did not fall below the center elevation of the sill block of $27 \mathrm{ft}$ during the temporary data collection period.

Based on the relation in equation 1 and the water level surface downstream from the crest, a description of the longitudinally changing water surface over the weir and its variation with streamflow rates was developed. The streamflow rate as compared to the water surface elevations, $Z_{1}$ through $Z_{4}$, is shown on figure 4 . The water-level data at points 3 and 4 were noisy owing to the readings being instantaneous and the water level logger's location downstream from the weir. As streamflow increases, the upstream (blue line) and downstream recorded values (red points) converge as the weir becomes submerged by tail-water.

\section{Water Depth}

Water depth is an important criterion in assessing the passability of any hydraulic structure because it is assumed that fish require a minimum depth to navigate the weir. The water depth $\left(D_{p}\right)$ at the center of the weir (the midpoint 


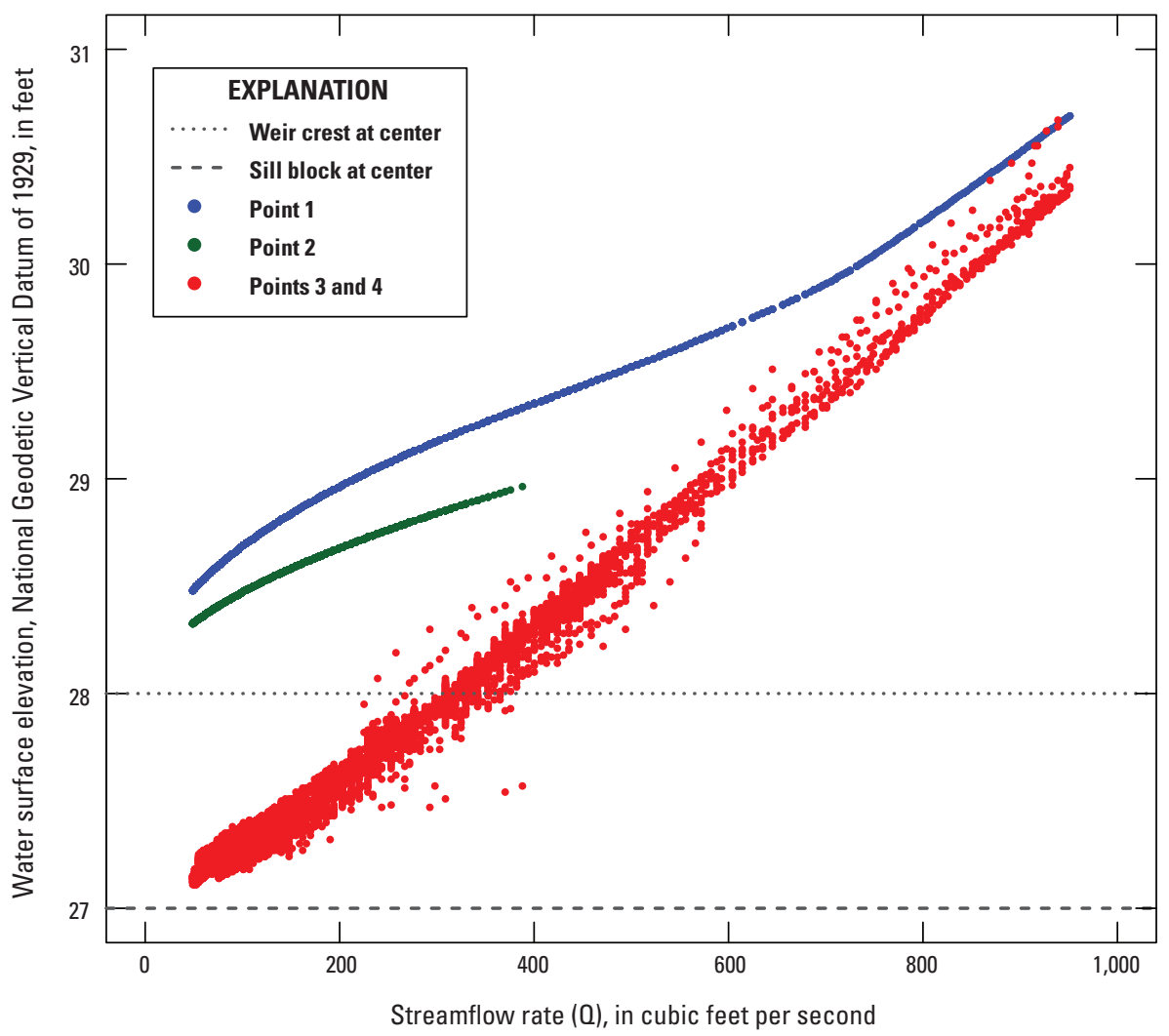

Figure 4. Streamflow rate $(0)$ as compared to water-surface elevation for each cross-sectional location along the U.S. Geological Survey Blackwells Mills streamgage (01402000) and weir, New Jersey. Location of streamgage is shown in figure 1. between the concrete abutments) at each point ( $p$ ) was calculated using the following equation:

$$
D_{p}=Z_{p}-a
$$

where

$$
Z_{p} \quad \text { is equal to the water surface elevation for }
$$
points $1,2,3$, and 4 ; and

$a \quad$ is equal to $27.50,28.00,26.84$, and $27.00 \mathrm{ft}$ NGVD 29 for points 1, 2, 3, and 4, respectively.

\section{Cross-Sectional Area}

The cross-sectional areas for the range of streamflow rates are needed to determine velocity at the various points along the weir because streamflow divided by area yields mean velocity. The following relation for cross-sectional area $\left(A_{p}\right)$, at each point $(p)$ was developed from the survey drawings (Work Progress Administration New Jersey, 1937):

$$
A_{p}=\left\{\begin{array}{c}
0 \text { if } Z_{p}<a \\
45\left(Z_{p}-a\right)+22.5\left(Z_{p}-a\right)^{2} \quad \text { if } a \leq Z_{p}<a+1 \\
90\left(Z_{p}-(a+1)\right)+67.5 \text { if } Z_{p} \geq a+1
\end{array}\right.
$$

Equation 3 is applicable when $Z_{p}$ is less than $30.7 \mathrm{ft}$, at which point streamflows are confined within the abutments of the weir. Above this point, the shape of the channel changes and the equation is no longer valid. Streamflows must exceed approximately $950 \mathrm{ft}^{3} / \mathrm{s}$ for the water surface elevation to exceed $30.7 \mathrm{ft}$ at any location along the weir. Historically, streamflows have exceeded this value less than 9 percent of the time during the migration season.

\section{Average Cross-Sectional Velocity}

Successful fish passage over hydraulic structures requires that water velocities do not exceed the maximum swimming speed of the fish. The average cross-sectional velocity $\left(V_{p}\right)$ for each point ( $p$ ) was calculated as a function of $Q$ and $A_{p}$, as follows:

$$
V_{p}=\frac{Q}{A_{p}}
$$

\section{Froude Number}

The Froude number - the ratio of inertial to gravitational forces - provides insight into whether a hydraulic jump may form. Because hydraulic jumps create changes in water velocities, turbulence, and aeration, they can create difficult conditions for fish passage. A Froude number of 1 represents 
the critical flow condition. Froude numbers above 1 indicate shallow, fast, supercritical streamflow; numbers below 1 correspond to deep, slow, subcritical streamflow.

Cross-sectional velocity and top width are the variables needed to calculate the Froude number. Velocity was previously determined using equation 4 . The equation to determine top width $\left(T_{p}\right)$, for each point $(p)$ was developed from survey drawings (Work Progress Administration New Jersey, 1937) using the following equation:

$$
T_{p}=\left\{\begin{array}{c}
0 \text { if } Z_{p}<a \\
45+2\left(Z_{p}-a\right) \tan 87.46^{\circ} \text { if } a \leq Z_{p}<a+1 \\
90 \text { if } Z_{p} \geq a+1
\end{array}\right.
$$

Equation 5 is applicable when $Z_{p}$ is less than $30.7 \mathrm{ft}$, as was true for equation 3 , which is when flows are contained within the abutments.

The Froude number $\left(F r_{p}\right)$ for each point $(p)$ was then calculated as a function of $V_{p}^{p}, A_{p}$, and $T_{p}$, as follows:

$$
F r_{p}=\frac{V_{p}}{\sqrt{g \frac{A_{p}}{T_{p}}}}
$$

\section{Estimated Conditions}

The computed hydraulic properties were examined in relation to the flow exceedances. The percentage of time when the hydraulic properties exceed the limitations of the fish species was then determined.

\section{Estimated Water Depth}

Estimated water depths generally increased with increasing streamflow for all points on the weir. Depths were lower at more downstream points than at upstream points for a given streamflow. Water depth was estimated at the center of the weir at each of the points at varying streamflow rate intervals. Boxplots of the estimated water depths are shown in figure 5. The depth criteria for American shad for 1-BD is $0.60 \mathrm{ft}$; and for 2-BDs is $1.20 \mathrm{ft}$. For alewife the 1-BD is $0.29 \mathrm{ft}$; and for 2-BDs is $0.58 \mathrm{ft}$. Blueback herring are not shown in figure 5 because they are nearly the same criteria as for alewife. The streamflow rate as compared to the flow exceedance during the migration season (streamflow data from 1921-2017) is also shown in figure $5 \mathrm{~A}$ and in table 3 ).

\section{Estimated Water Velocity}

Water velocity is an important criterion for determining whether or not a barrier to fish passage may exist. Boxplots of the water velocity $(V p)$ at each of the points for varying streamflow rate intervals are shown in figure 6. Superimposed onto each box plot are the maximum velocity criteria for alewife and blueback herring at $8 \mathrm{ft} / \mathrm{s}$ and American shad at
$10 \mathrm{ft} / \mathrm{s}$. The streamflow rate compared to the flow exceedance during the migration season is shown in figure $6 \mathrm{~A}$ and table 3 .

Due to local acceleration, average cross-sectional water velocity increases as the streamflow rate increases over the weir crest (point 2) and immediately upstream (point 1). Nevertheless, estimated velocities were below $8 \mathrm{ft} / \mathrm{s}$ throughout the entire streamflow range (from 50 to $750 \mathrm{ft}^{3} / \mathrm{s}$ for point 1 and from 50 to $400 \mathrm{ft}^{3} / \mathrm{s}$ for point 2). Conversely, velocity decreases as the streamflow increases at locations above the sill of the weir because of the effect of the tail-water imposing subcritical conditions over the sill at flows greater than about $300 \mathrm{ft}^{3} / \mathrm{s}$. Velocities exceed $8 \mathrm{ft} / \mathrm{s}$ along the weir only at point 4 and when the flow is less than $300 \mathrm{ft}^{3} / \mathrm{s}$; however, the median of the average cross-sectional velocity taken across each streamflow interval never exceeds $8 \mathrm{ft} / \mathrm{s}$ at any point.

Although the average cross-sectional velocity has been presented, the true velocity distribution over any weir and through any real, prismatic channel will be nonuniform on account of the effects of turbulence and friction. For example, velocities near the surface will be higher than the average cross-sectional velocity. Accordingly, fish moving near the surface of the water may face a more difficult ascent and the vertical velocity distribution may increase the challenging conditions demonstrated by the average velocities calculated for low tail-water conditions.

As water falls over a control structure like the Blackwells Mills weir, the water accelerates spatially along the weir. Moreover, when the weir is unsubmerged by tail-water, the flow may transition from a subcritical state at or near point 2 (the weir crest) to a supercritical state at points 3 and 4 . Much of the preceding analysis is predicated on the generally accepted practice of positing the critical state over the crest. Thus, the water may continue to accelerate to a supercritical state on the downstream face of the weir. Importantly, calculations of velocity at points 2 and 3 do not represent the maximum water velocity over the weir that may occur between the crest and the sill (at a location between points 2 and 3). A theoretical maximum velocity $\left(V_{\max }\right)$ can be estimated by ignoring frictional forces and assuming that the entire head differential (the difference in water-surface elevation between the Blackwells Mills streamgage and the downstream temporary waterlevel logger) is converted to kinetic energy along the weir.

$$
V_{\max }=\sqrt{2 g\left(Z_{1}-Z_{4}\right)}
$$

A plot of this theoretical maximum average crosssectional velocity for conditions when the downstream water level (points 3 and 4) is less than the height of the weir crest (that is, the weir is unsubmerged by tail-water) is shown on figure 7. Superimposed on figure 7 are the maximum velocity criteria for alewife and blueback herring $(8 \mathrm{ft} / \mathrm{s})$ and American $\operatorname{shad}(10 \mathrm{ft} / \mathrm{s})$. 


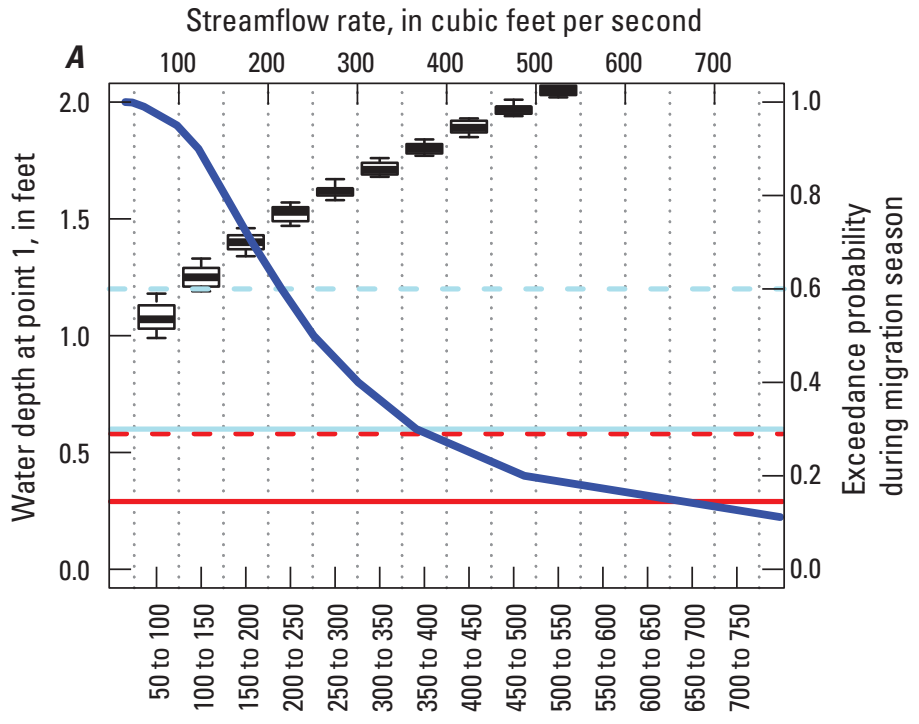

Streamflow rate interval, in cubic feet per second

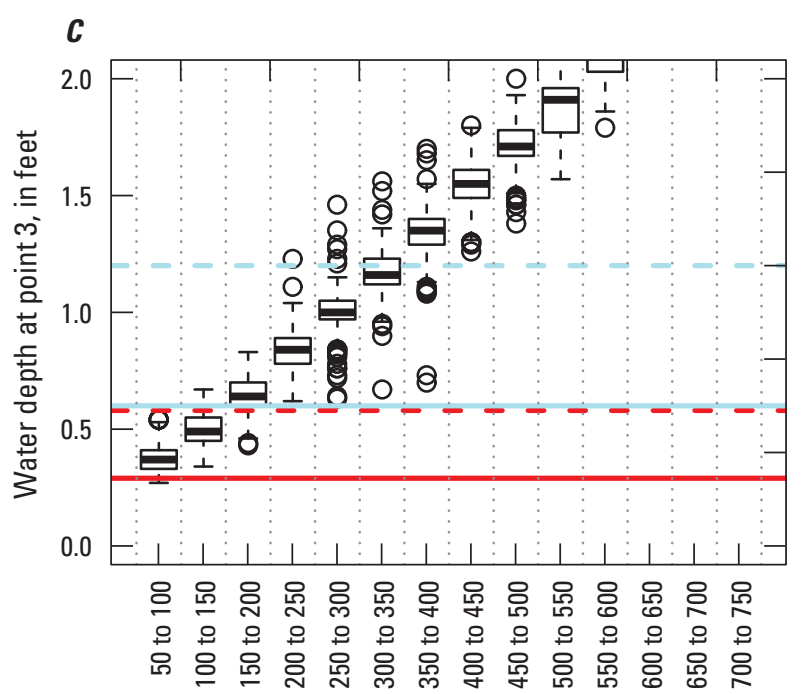

Streamflow rate interval, in cubic feet per second

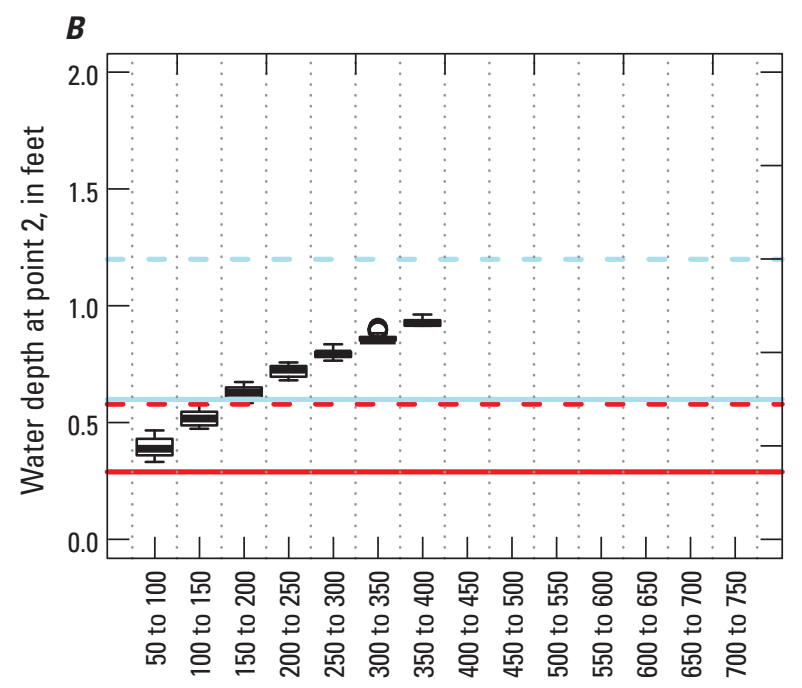

Streamflow rate interval, in cubic feet per second

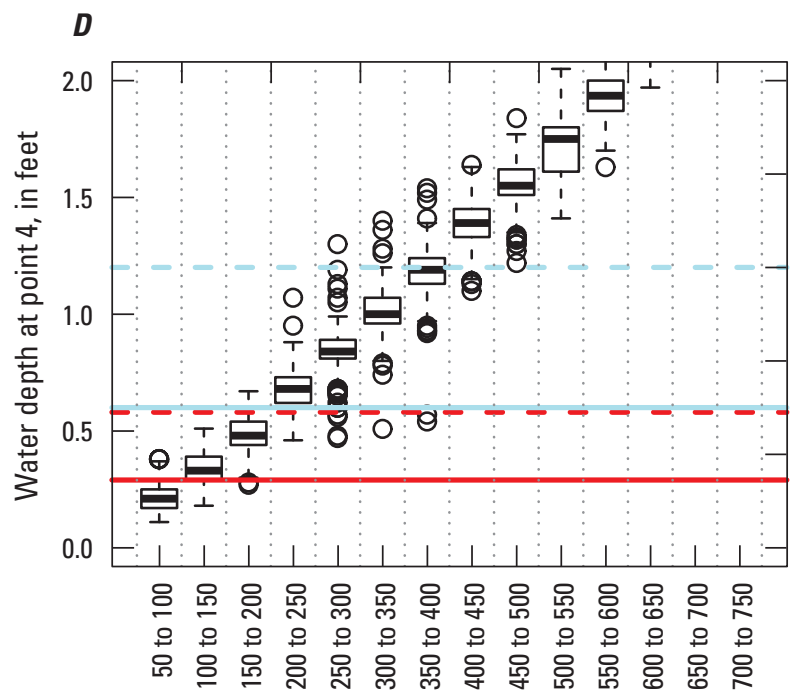

Streamflow rate interval, in cubic feet per second

\section{EXPLANATION}

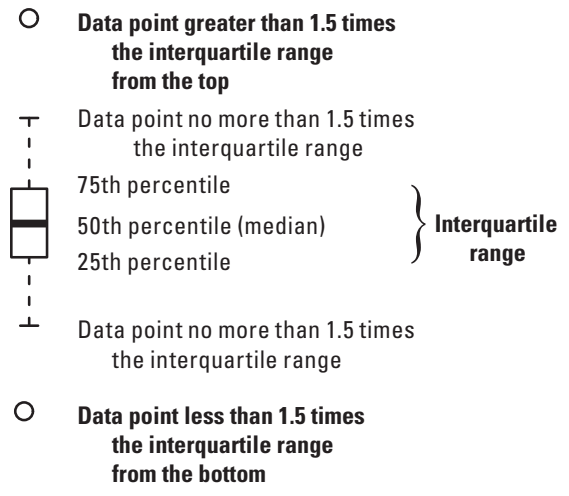

Fish species by body depth number (1)

- Alewife body depth (1)

- - Alewife body depths (2)

American shad body depth (1)

American shad body depths (2)

Migration season exceedence probability

Figure 5. Estimated water depth at the center of the Blackwells Mills weir, New Jersey for $A$, point 1; $B$, point 2; $C$, point 3; and $D$, point 4 at varying streamflow rate intervals ranging from 50 to 750 cubic feet per second $\left(\mathrm{ft}^{3} / \mathrm{s}\right)$ at $50 \mathrm{ft}^{3} / \mathrm{s}$ intervals. Location of points is shown on figure 3 . 
Table 3. Streamflow conditions that result in insufficient depth at the center of the Blackwells Mills weir, New Jersey, for the given depth criteria from 1921 to 2017.

[Location of point shown in figure 3. The values in parentheses correspond to the fraction of time during migration season from 1921 to 2017 when daily mean streamflow exceeded the flows reported in each table cell. --, no depth barrier; <, less than]

\begin{tabular}{|c|c|c|c|c|c|c|}
\hline \multirow{3}{*}{ Point } & \multicolumn{6}{|c|}{ Streamflow, in cubic feet per second } \\
\hline & \multicolumn{3}{|c|}{1 body depth } & \multicolumn{3}{|c|}{2 body depth } \\
\hline & Alewife herring & Blueback herring & American shad & Alewife herring & Blueback herring & American shad \\
\hline 1 & -- & -- & -- & -- & -- & $\begin{array}{l}<50 \text { to } 100 \\
\quad(0.998 \text { to } 0.95)\end{array}$ \\
\hline 2 & -- & -- & $\begin{array}{l}<100 \text { to } 150 \\
\quad(0.95 \text { to } .81)\end{array}$ & $\begin{array}{l}<100 \text { to } 150 \\
\quad(0.95 \text { to } .81)\end{array}$ & $\begin{array}{l}<50 \text { to } 100 \\
\quad(0.998 \text { to } 0.95)\end{array}$ & $\begin{array}{l}{ }^{1}<350 \text { to } 400 \\
\quad(0.32 \text { to } 0.27)\end{array}$ \\
\hline 3 & -- & -- & $\begin{array}{l}<100 \text { to } 150 \\
\quad(0.95 \text { to } 0.81)\end{array}$ & $\begin{array}{l}<100 \text { to } 150 \\
\quad(0.95 \text { to } 0.81)\end{array}$ & $\begin{array}{l}<100 \text { to } 150 \\
\quad(0.95 \text { to } 0.81)\end{array}$ & $\begin{array}{l}<300 \text { to } 350 \\
\quad(0.40 \text { to } 0.32)\end{array}$ \\
\hline 4 & $\begin{array}{l}<50 \text { to } 100 \\
\quad(0.998 \text { to } 0.95)\end{array}$ & $\begin{array}{l}<50 \text { to } 100 \\
\quad(0.998 \text { to } 0.95)\end{array}$ & $\begin{array}{l}<150 \text { to } 200 \\
\quad(0.81 \text { to } 0.65)\end{array}$ & $\begin{array}{l}<150 \text { to } 200 \\
\quad(0.81 \text { to } 0.65)\end{array}$ & $\begin{array}{l}<150 \text { to } 200 \\
\quad(0.81 \text { to } 0.65)\end{array}$ & $\begin{array}{l}<350 \text { to } 400 \\
\quad(0.32 \text { to } 0.27)\end{array}$ \\
\hline
\end{tabular}

${ }^{1}$ Velocity estimates were not made beyond this interval of flow at point 2 . Based on figure 3, the true values are likely higher than this flow interval.

\section{Estimated Froude Number}

Froude number along a weir is an important indicator for determining whether or not a full or partial barrier to fish passage may exist. A comparison of supercritical $\left(\mathrm{Fr}_{p}\right.$ greater than 1) and subcritical ( $F_{p}$ less than 1) streamflow rates at different locations along the weir at a wide range of streamflow rates is shown in figure 8 . The dashed black line represents the critical flow condition $\left(F r_{p}=1\right)$ of the stream. The streamflow rate as compared to the flow exceedance during the migration season is shown in figure $8 \mathrm{~A}$ and in table 3 . Point 1 is within the subcritical range in the entire streamflow range from 50 to $750 \mathrm{ft}^{3} / \mathrm{s}$. The streamflow at point 2 (the weir crest) is roughly at the critical condition over the entire range of streamflow. The streamflow at point 3 tends to be supercritical at streamflow rates less than $250 \mathrm{ft}^{3} / \mathrm{s}$ and subcritical at streamflows greater than $250 \mathrm{ft}^{3} / \mathrm{s}$. The streamflow at point 4 is highly supercritical at streamflows less than $300 \mathrm{ft}^{3} / \mathrm{s}$ and transitions to subcritical at streamflows greater than $300 \mathrm{ft}^{3} / \mathrm{s}$. This transition indicates that a hydraulic jump does not occur on the weir at streamflow rates less than $300 \mathrm{ft}^{3} / \mathrm{s}$ but may occur at higher streamflow rates when points 3 and 4 are in the subcritical state and point 2 is near the critical condition. In addition, the peak average cross-sectional water velocity along the weir likely occurs at the sill block for streamflow rates less than $300 \mathrm{ft}^{3} / \mathrm{s}$ because it seems that a hydraulic jump has not formed along the weir. Once the flow is subcritical at points 3 and 4 , the peak velocity will occur between the weir crest and the sill (as described in the "Estimated Water Velocity" section).

The formation of a hydraulic jump at Blackwells Mills weir is documented in figure 2 ; the photograph in figure $2 \mathrm{~A}$ was taken at a streamflow of approximately $710 \mathrm{ft}^{3} / \mathrm{s}$, whereas the photograph in figure $2 B$ was taken at a streamflow of approximately $87 \mathrm{ft}^{3} / \mathrm{s}$. At the higher streamflow rate, a hydraulic jump forms along or immediately downstream from the sill, corresponding well with the results shown in figure 8. At the lower streamflow rate, streamflow is supercritical along the sill and highly turbulent near the sill block at the downstream end of the weir. Although a hydraulic jump is not clearly formed in the photograph, one may occur directly above the sill block or immediately downstream. The Froude number estimates (fig. 8) predict a jump would not occur along the sill at this low streamflow, but that does not discount the possibility of a jump occurring farther downstream from the block. In figure $2 B$ the flowing water seems as if it is dropping from the sill block down into the tail-water along the far side of the weir. This drop may be occurring as the elevation of the sill block increases from $27 \mathrm{ft}$ in the center to $28.02 \mathrm{ft}$ at the abutments, given the tail-water-surface elevation was $27.26 \mathrm{ft}$ at the streamflow rate of $87 \mathrm{ft}^{3} / \mathrm{s}$. The transitions in state and the drop further illustrate the complex flow field at the weir, particularly at low streamflows.

The presence of a hydraulic jump on the Blackwells Mills weir is not unusual. Hydraulic jumps occur over many control structures precisely because supercritical conditions are induced on the downstream face of a weir before returning the subcritical conditions on the sill or downstream in the river. Indeed, the sill block on the weir was likely designed to induce the jump on the concrete and thus prevent erosion and undercutting at the toe. However, fish-passage structures are designed to prevent the occurrence of jumps, given that hydraulic jumps can affect the behavior and physical ability of migratory fishes in negotiating and passing velocity barriers (Beach, 1984; Larinier, 2002; Haro and others, 2004). 


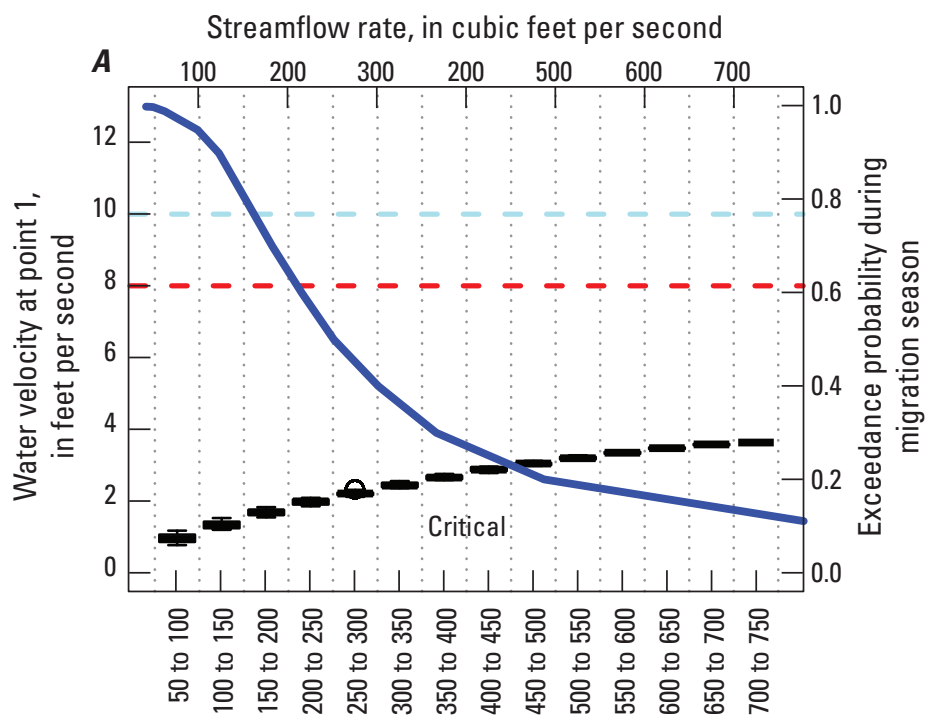

Streamflow rate interval, in cubic feet per second

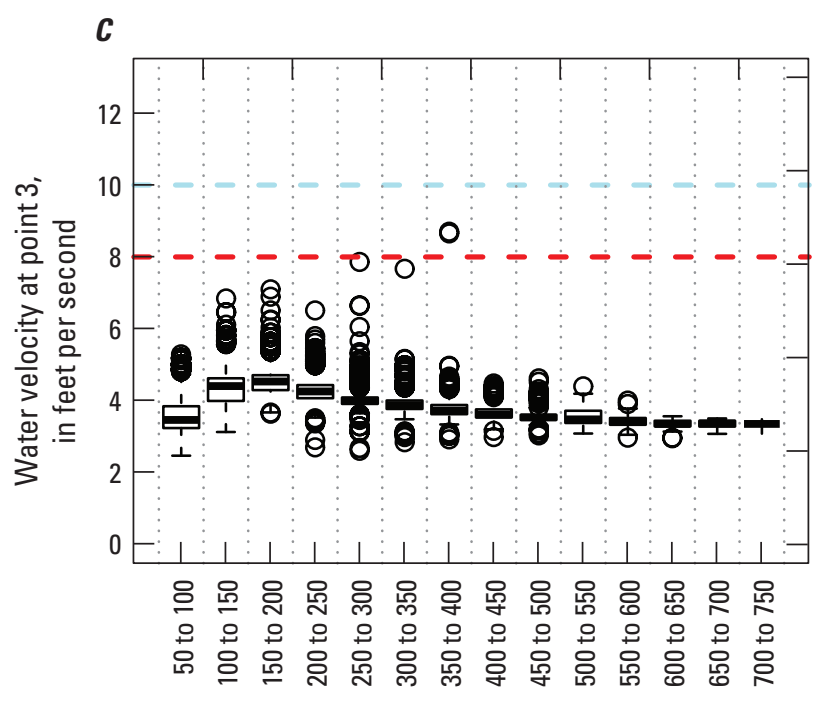

Streamflow rate interval, in cubic feet per second

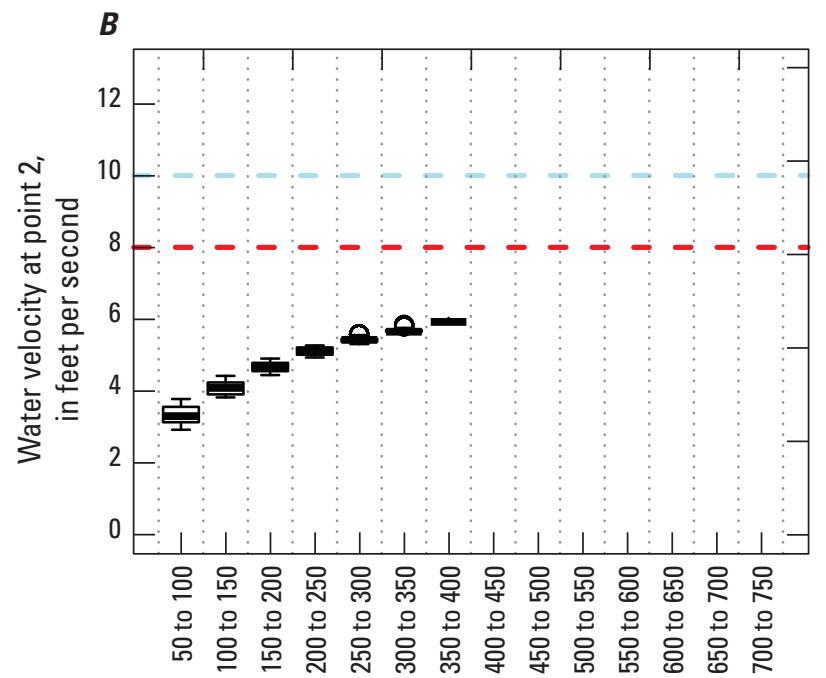

Streamflow rate interval, in cubic feet per second

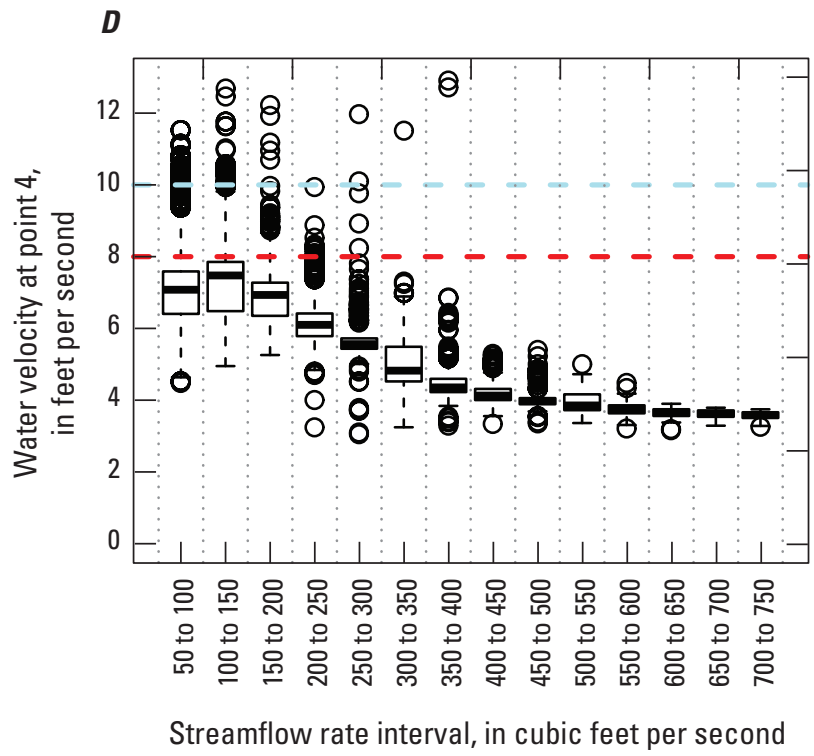

EXPLANATION
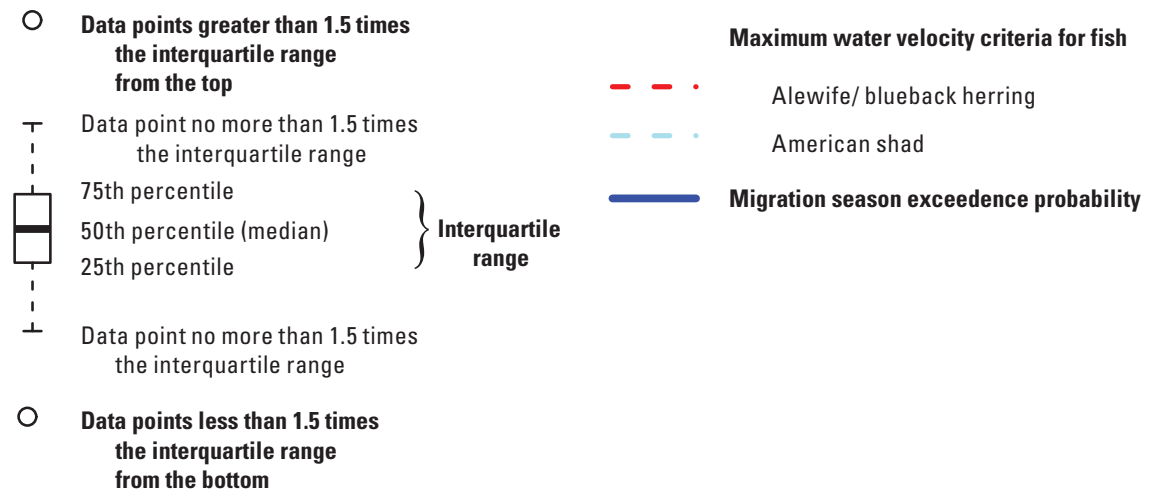

Figure 6. The average cross-sectional water velocity at the Blackwells Mills weir, New Jersey, for $A$, point $1 ; B$, point 2; $C$, point 3 ; and $D$, point 4 with varying streamflow rate intervals ranging from 50 to 750 cubic feet per second ( $\left.\mathrm{ft}^{3} / \mathrm{s}\right)$ at $50 \mathrm{ft}^{3} / \mathrm{s}$ intervals. Location of points is shown in figure 3 . 


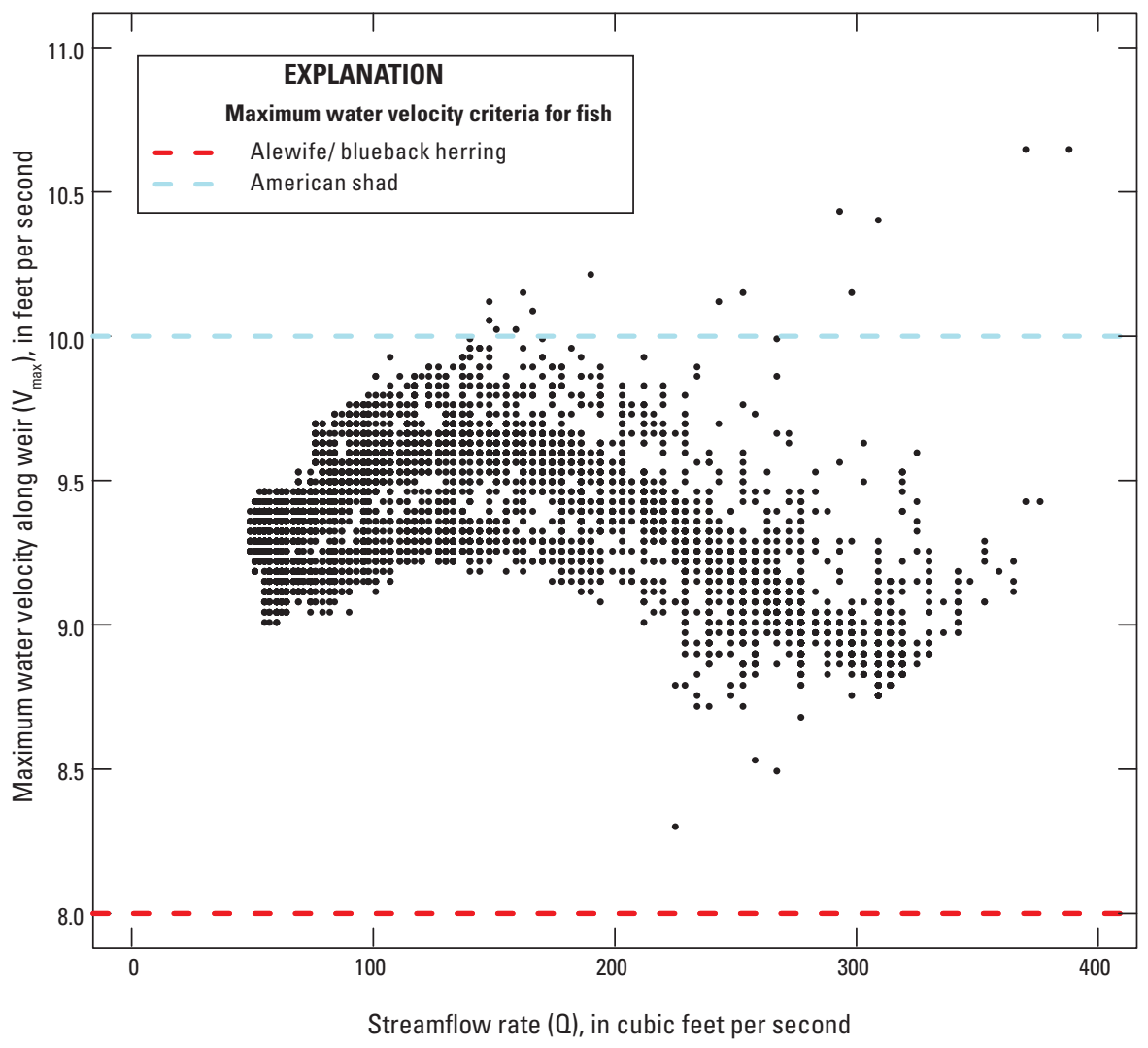

Figure 7. Theoretical maximum average cross-sectional water velocity along the Blackwells Mills weir, New Jersey. Location of weir shown in figure 1.

\section{Fish Passability During the Period of Migration}

During low-flow conditions, the depth of water over the weir does not meet the determined requirements of the selected fish species, whereas velocity does not seem to be a barrier to fish passage. The potential limitations of each in the context of streamflow exceedances are discussed in the following sections.

\section{Depth Limitations}

The point along the weir that is most restrictive in terms of depth is point 4 , reaching limiting depths at higher streamflows than points $1-3$. Streamflows and associated percentflow exceedances that failed to meet the minimum streamflowdepth criteria are given in table 3 . The depth criterion was evaluated at the center of the weir at all four points. Seasonal persistence of these unsuitable conditions is indicated by the migration season streamflow exceedances. Using a criterion of 1-BD for alewife and blueback herring, a depth barrier exists at point 4 below $100 \mathrm{ft}^{3} / \mathrm{s}$, which occurs on average 5 percent of the time during the migratory season. Under a 2-BD criterion, a depth barrier exists at point 4 below $200 \mathrm{ft}^{3} / \mathrm{s}$, which occurs on average 35 percent of the time during the migratory season. Depth limitations were more severe for the deeper-bodied American shad. At 1-BD for American shad, a depth barrier exists at point 4 below $200 \mathrm{ft}^{3} / \mathrm{s}$, which occurs on average 35 percent of the time during the migratory season. Under a 2-BD criterion, a depth barrier exists at point 4 below $400 \mathrm{ft}^{3} / \mathrm{s}$, which occurs on average 73 percent of the time during the migratory season.

\section{Velocity Limitations}

Streamflows and associated exceedances that were greater than the maximum water velocity criterion are more difficult to interpret. Because the median of $V_{p}$ taken across each flow interval never exceeded $8 \mathrm{ft} / \mathrm{s}$ (maximum velocity criterion for alewife and blueback herring) at any flow, it might be concluded that a velocity barrier does not exist for all of the target species at the weir at any modeled streamflow. However, accounting for streamflow acceleration to a supercritical state over the weir crest and face, the estimated $V_{\max }$ over this region generally ranges between 8.5 and $10.0 \mathrm{ft} / \mathrm{s}$ 


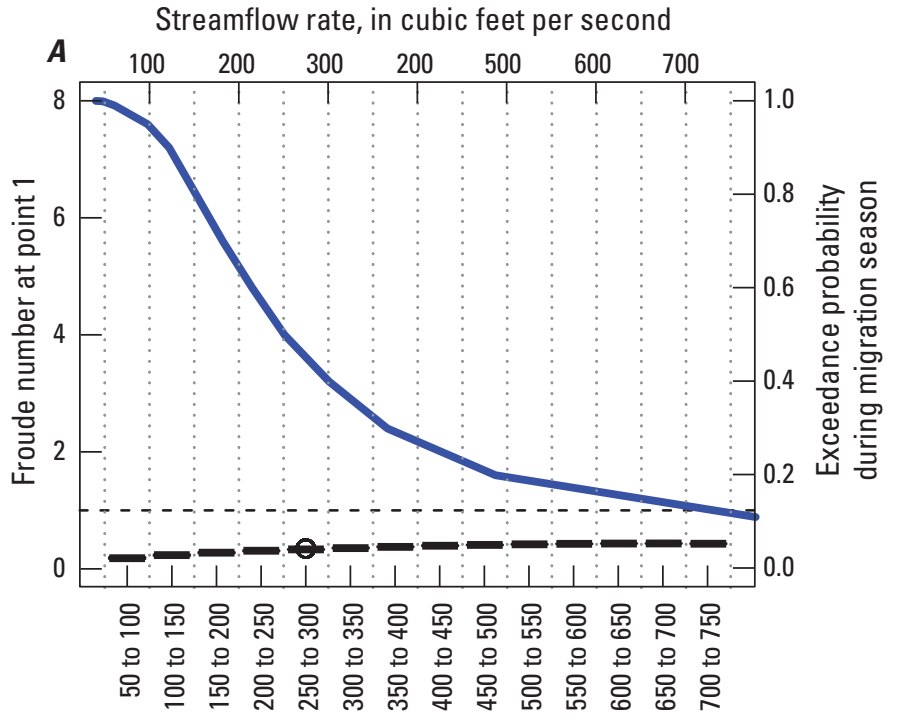

Streamflow rate interval, in cubic feet per second

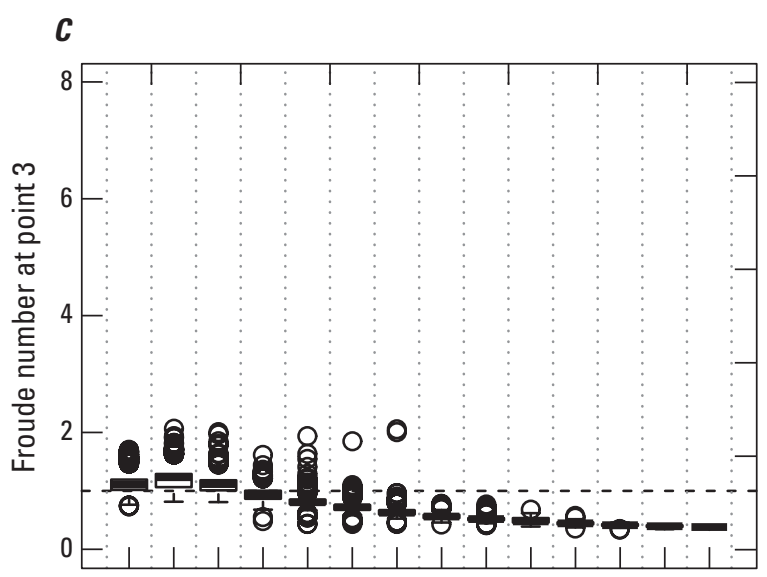

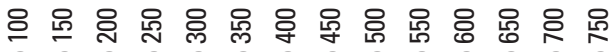

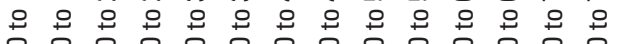

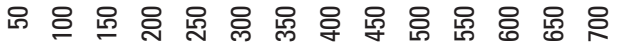

Streamflow rate interval, in cubic feet per second

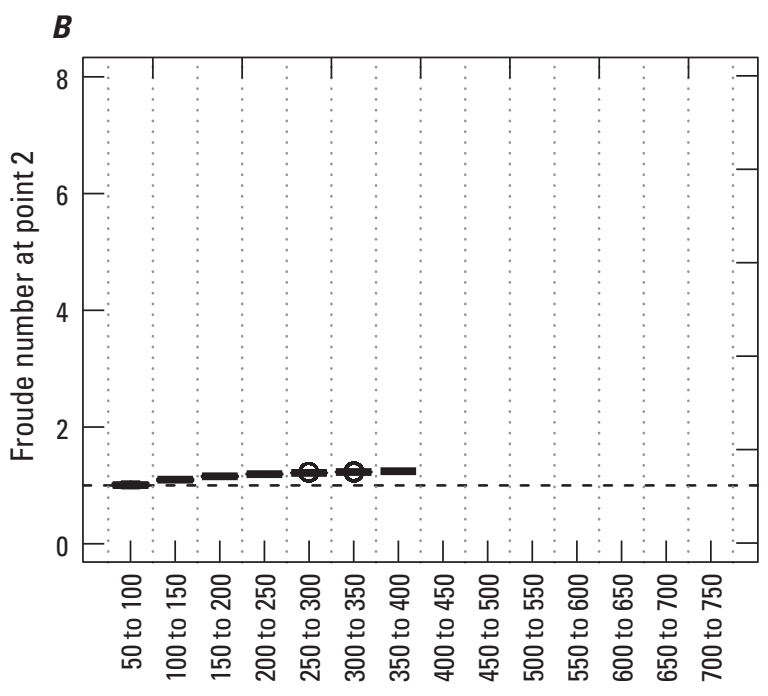

Streamflow rate interval, in cubic feet per second

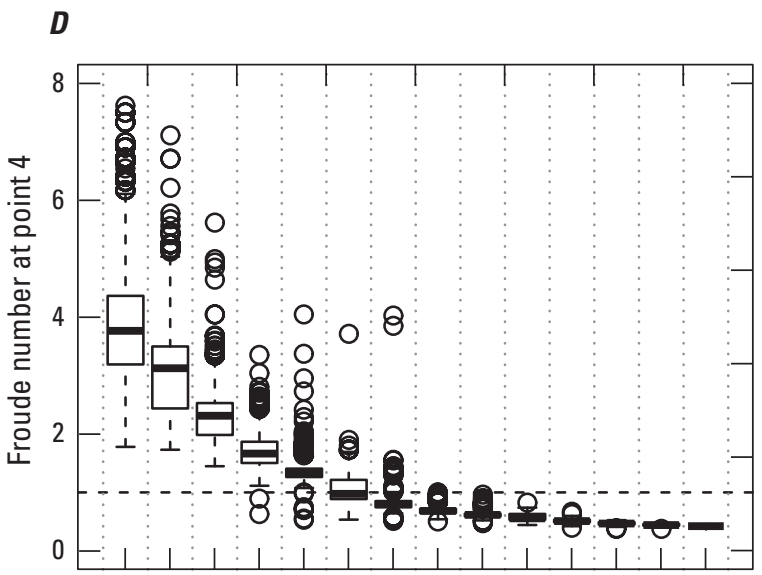

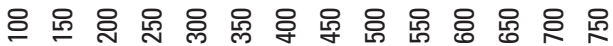

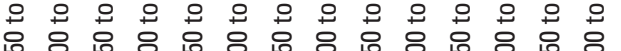

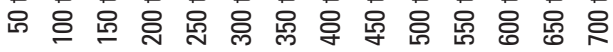

Streamflow rate interval, in cubic feet per second

\section{EXPLANATION}

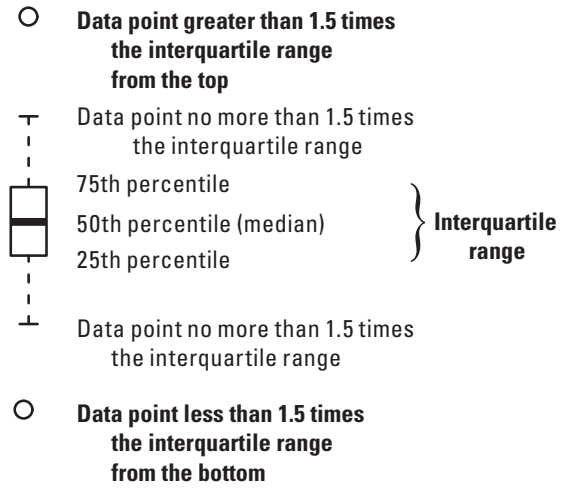

Migration season exceedence probability 
at streamflows less than $320 \mathrm{ft}^{3} / \mathrm{s}$ (when the weir is unsubmerged), which is above the maximum U.S. Fish and Wildlife Service limit for the grouping of alewife and blueback herring (U.S. Fish and Wildlife Service, 2016) but generally below the limit for American shad $(10 \mathrm{ft} / \mathrm{s})$.

\section{Summary}

This report documents the methods and results of a desktop modelling exercise to evaluate the potential ability of three anadromous fish species (Alosa sapidissima [American shad], Alosa pseudoharengus [alewife], and Alosa aestivalis [blueback herring]) to pass upstream over the weir located beside the U.S. Geological Survey Blackwells Mills streamgage (01402000) on the Millstone River, New Jersey, under a wide range of streamflow rates.

Recorded water levels and flow data were used to estimate water depths and velocities over the weir, as well as flow exceedances occurring during the migratory period. The gross estimates indicated that alewife and blueback herring would be limited by a depth barrier of 1-body depth (BD) during 5 percent of the annual migratory season (April 14 to May 28). A more conservative limit of 2 BDs results in a depth barrier about 35 percent of the migratory season. For deeperbodied fish like American shad, a depth limitation may occur with flows less than about 200 cubic feet per second (1-BD criterion), resulting in a barrier 35 percent of the time during the migration season. Using the 2-BD criterion for American shad would result in a barrier 73 percent of the time during the migration season. Blueback herring and alewife, which require less water depth but do not possess the higher absolute sprint swimming speeds of American shad, may encounter a velocity barrier over the weir at some low flows.

This evaluation was largely a desktop modelling exercise and the water velocity and depth calculations may not represent actual field conditions; however, the calculations give an indication of potential conditions that may create a barrier for fish passage at the Blackwells Mills weir. Behaviors and swimming capabilities of the fish species used in this evaluation are also estimated, and actual behaviors at the Blackwells Mills weir are currently unknown. Additional study of the Blackwells Mills weir and its potential to act as a barrier (as well as streamgaging weirs in general) is warranted. Specific studies would include further field research to determine if the target fish species (American shad, alewife, and blueback herring) are in fact attempting to migrate as far upstream along the Millstone River to Blackwells Mills weir or remain mainly in the Raritan River. Laboratory (physical or numerical model) measurements of hydraulics at various flows, and additional studies of fish behavior relative to low-head weirs, particularly the ability of fishes to pass through low-flow depths and over vertical drops such as ogee weir faces are also suggested. These studies would allow refinement of passability models and improve the ability to determine whether low-head weirs function as barriers at low-flow conditions.

\section{References Cited}

Beach, M.H., 1984, Fish pass design - Criteria for the design and approval of fish passes and other structures to facilitate the passage of migratory fish in rivers: Lowestoft, United Kingdom, Ministry of Agriculture, Fisheries, and Food, $44 \mathrm{p}$.

Crowe, C.T., Elger, D.F., and Roberson, J.A., 2005, Engineering fluid mechanics (8th ed.): Hoboken, N.J., John Wiley \& Sons, Inc., 656 p.

Dingman, S.L., 1994, Physical hydrology: New York, Macmillan College Publishing Company, 575 p.

Haro, Alex, Castro-Santos, Theodore, Noreika, John, and Odeh, Mufeed, 2004, Swimming performance of upstream migrant fishes in open-channel flow-A new approach to predicting passage through velocity barriers: Canadian Journal of Fisheries and Aquatic Science, v. 61, p. 1590-1601

Larinier, M., 2002, Biological factors to be taken into account in the design of fishways, the concept of obstructions to upstream migration: Bulletin Français de la Pêche et de la Pisciculture, v. 364, p. 28-38.

New Jersey Department of Environmental Protection, 2013, American shad restoration in the Raritan River: New Jersey Department of Environmental Protection Fish and Wildlife Grant F-48-R-25, 9 p.

Princeton Hydro, LLC, 2011, Feasibility study-Blackwells Mills Dam removal, NJ Dam No. 25-203, Millstone River: Ringoes, N.J., Princeton Hydro Project No. 0390.004, 67 p.

U.S. Fish and Wildlife Service, 2017, Fish passage engineering design criteria: Hadley, Mass., U.S. Fish and Wildlife Service, Northeast Region R5, 224 p.

U.S. Geological Survey, 2016, USGS 01402000 Millstone River at Blackwells Mills NJ, in USGS water data for the nation: U.S. Geological Survey National Water Information System database, accessed January 26, 2017, at https://waterdata.usgs.gov/nwis/uv/?site_no $=01402000$.

Work Progress Administration New Jersey, 1937, Millstone River Riparian and Stream Survey Map and Plans: Work Progress Administration New Jersey Map Sheet 11, 34 p. 

For more information concerning this report, contact: Director, Leetown Science Center

U.S. Geological Survey

11649 Leetown Road

Kearneysville, WV 25430

gs_nea_Isc_publications@usgs.gov

or visit our website at:

https://www.lsc.usgs.gov/

Publishing support provided by the

Pembroke and Rolla Publishing Service Centers 


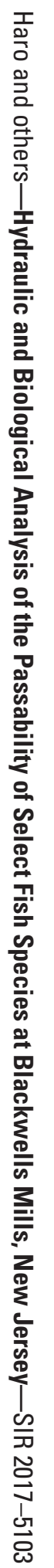

